\title{
JUDICIAL REVIEW OF LABOR AGREEMENTS: LESSONS FROM THE SPORTS INDUSTRY
}

\author{
JOHN C. WEISTART*
}

Much of the recent legal controversy in the professional sports industry has emanated from the clubs' efforts to limit the movement of players among teams. The traditional restraints have included devices such as the draft system, reserve and option clauses, and arrangements requiring that compensation be paid to a club whose player has accepted employment with another member of the same league. ${ }^{1}$ Until the early 1970 s, these player restraints were treated as matters of private contract between club and player. Except for occasional decisions interpreting the breadth of the club's claim or clarifying the mechanism for a club's unilateral renewal of a contract, ${ }^{2}$ the judiciary played no significant role in overseeing the operation of the restraint system. The treatment of the restraints as a private law matter changed dramatically in the mid-1970s. The advent of durable players' unions and the commencement of a series of antitrust challenges interjected the law's institutions, especially the courts, rather deeply into the issue of player mobility. ${ }^{3}$ The beneficial effect of these cases was to open the way for greater player input, typically through collective bargaining, into the shaping of

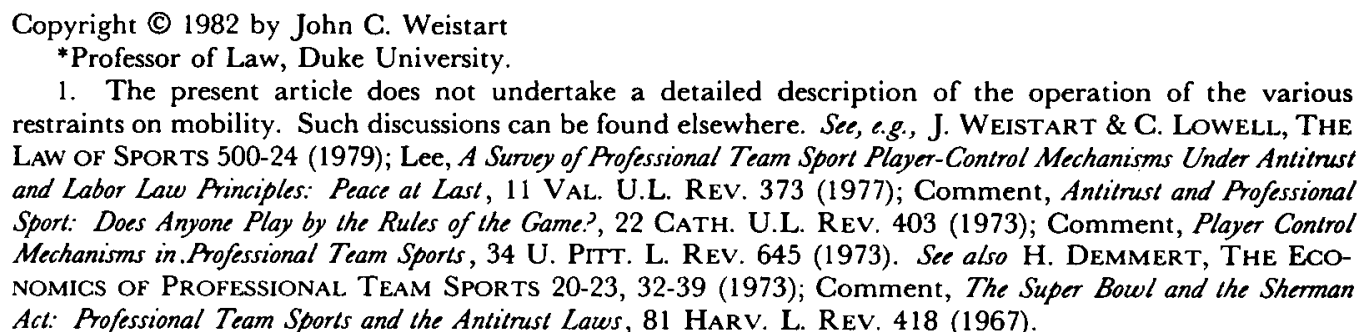

2. See, e.g., Hennigan v. Chargers Football Co., 431 F.2d 308 (5th Cir. 1970); Dallas Cowboys Football Club, Inc. v. Harris, 348 S.W.2d 37 (Tex. Civ. App. 1961).

3. The present discussion is most germane to the owner-player relationships that exist in the professional football, basketball, and hockey leagues. The pertinent cases began as antitrust attacks upon the traditional player restraints in these leagues. Because baseball enjoys a general exemption from the antitrust laws, the player control mechanisms in baseball, especially the reserve clause, are not directly affected by the principles considered here. See, e.g., Flood v. Kuhn, 316 F. Supp. 271 (S.D.N.Y. 1970), affd, 443 F.2d 264 (2d Cir. 1971), affd, 407 U.S. 258 (1972). Although there have been significant changes in the restraint system used in baseball, these changes have resulted from developments outside the antitrust sphere, such as an arbitrator's interpretation of the standard player contract and a subsequent collective bargaining agreement. See Kansas City Royals Baseball Corp. v. Major League Baseball Players Ass'n, 409 F. Supp. 233 (W.D. Mo.), affd, 532 F.2d 615 (8th Cir. 1976); In re Twelve Clubs Comprising Nat'l League of Professional Baseball Clubs v. Major League Baseball Players Ass'n (Messersmith-McNally Arbitration), 66 Lab. Arb. 101 (1975) (Seitz, Arb.). While labor law principles and the institution of collective bar: gaining have also been important in defining the restraints that presently exist in sports other than baseball, the labor issues in these settings are, as is discerned later, entwined with antitrust concerns which have not affected the baseball industry. 
these important employment terms. The player restraint cases do, however, leave some residual concerns about the role of the courts in overseeing the collective bargaining process. The issues were not presented to the courts as matters of pure labor law. Antitrust policies were early implicated and later proceedings involved issues relating to the settlement of class actions. Both of these areas tolerate a higher degree of judicial involvement in the adjustment of private agreements than do the labor laws. One of the issues which lingers after the sports cases is whether the courts have reached the proper accommodation between the competing policies on judicial review. This article undertakes to trace the development of the player restraint litigation and to suggest several respects in which greater deference to established labor policies will have a clarifying influence in the future.

\section{The Threshold fOR THE LABOR EXEMPTION}

With one exception, the antitrust suits challenging the traditional player restraints were brought by professional athletes who asserted that the limitations on player mobility artificially restricted competition among employers for the athletes' services. ${ }^{4}$ The preliminary rulings in these cases showed that the courts were definitely inclined to find significant antitrust problems. ${ }^{5}$ But before reaching the substantive antitrust issues, the courts in each case were confronted with the argument by the defendant clubs that the exemption afforded agreements reached in collective bargaining removed the disputed restraints from antitrust scrutiny. The leagues could each point to the fact that their players were unionized and suggest that the rules in question either had been or could be considered at the bargaining table. These contentions were rejected for a variety of reasons in the first several cases to arise. ${ }^{6}$ Only later after the antitrust litigation had neutralized the original restraints, did cases arise in which courts found sufficient bargaining to warrant immunity. ${ }^{7}$

The background for these claims of immunity lies in the early efforts of unions to avoid having their collective activities treated as illegal restraints of trade under the Sherman Act. ${ }^{8}$ Although there was a period in which the treatment of the

4. The exception was Philadelphia World Hockey Club, Inc. v. Philadelphia Hockey Club, Inc., 351 F. Supp. 462 (E.D. Pa. 1972), in which a rival league complained that the NHL's restraints operated improperly to limit the plaintiff's access to playing talent.

5. Mackey v. NFL, 407 F. Supp. 1000 (D. Minn. 1975), affd in part, rev'd in part, 543 F.2d 606 (8th Cir. 1976); Robertson v. NBA, 389 F. Supp. 867 (S.D.N.Y.), modified, 1975-2 Trade Cas. ๆ 60,448 (S.D.N.Y.); Kapp v. NFL, 390 F. Supp. 73 (N.D. Cal. 1974). See also Smith v. Pro Football, Inc., 420 F. Supp. 738 (D.D.C. 1976), affd, 593 F.2d 1173 (D.C. Cir. 1978).

6. See, e.g., Smith v. Pro Football, Inc., 420 F. Supp. 738 (D.D.C. 1976), affd on other grounds, 593 F.2d 1173 (D.C. Cir. 1978); Mackey v. NFL, 407 F. Supp. 1000 (D. Minn. 1975), affd in part, rev'd in part, 543 F.2d 606 (8th Cir. 1976); Robertson v. NBA, 389 F. Supp. 867 (S.D.N.Y.), modified, 1975-2 Trade Cas. I 60,448 (S.D.N.Y.); Kapp v. NFL, 390 F. Supp. 73 (N.D. Cal. 1974).

7. See McCourt v. California Sports, Inc., 600 F.2d 1193 (6th Cir. 1979), rev'g 460 F. Supp. 904 (E.P. Mich. 1978). See also Reynolds v. NFL, 584 F. 2d 280, 288 (8th Cir. 1978).

8. 15 U.S.C. $\S \S 1-7$ (1976). See, e.g., United Mine Workers v. Pennington, 381 U.S. 657 (1965); United States v. Hutcheson, 312 U.S. 219 (1941); Norris-LaGuardia Act, Pub. L. No. 65, 47 Stat. 70 (1932) (amended at 29 U.S.C. $\$ \S 101-15$ (1976)); Meltzer, Labor Unions, Collective Bargaining, and the Antitrust Laws, 
union's traditional economic tools was in doubt, it was gradually accepted that labor policy must be accommodated under the antitrust laws. The need for an adjustment is suggested by a variety of concerns. As an initial matter, there appears to be a fundamental conflict between the goals of the antitrust laws and the desire of employees to engage in collective activity. ${ }^{9}$ In fact, the employees' basic economic weapons-strikes, pickets, and boycotts-do restrain trade. Moreover, collective bargaining terms on a variety of issues, including seniority, standard wage rates, and even hours of work, typically represent a union's effort to reduce competition among employees. Since both economic coercion and standardization of employment terms through collective bargaining are protected labor activities, the concern for unrestrained competition in commercial markets cannot be extended with full force to the labor sphere. ${ }^{10}$

Another concern of equal import flows from the particular regime for regulating collective bargaining which was built into our basic labor law scheme. The mechanisms for furthering bargaining were the protection of the right to organize and the imposition on the employer of a duty to bargain. ${ }^{11}$ Except at the extremes, the system makes no assumption about what the terms of the final bargain should be and there is no vehicle for judicial or administrative oversight to insure that the terms agreed to are reasonable. ${ }^{12}$ The full implementation of this labor policy of unrestrained bargaining requires that the availability of review under other laws, including the antitrust laws, be carefully evaluated and limited where necessary. ${ }^{13}$

None of the several Supreme Court precedents dealing with the labor exemption involve situations in which an employer was attempting to assert the exemptions against claims raised by employees, and thus do not directly address the critical issues raised in the sports cases. ${ }^{14}$ The Supreme Court's decisions do, however, serve to underscore that the availability of the exemption is greatly influenced by the question of whom the disputed practice affects. A bargaining relationship which covers an entire market raises the prospect of union-manage-

32 U. ChI. L. Rev. 659 (1965); Winter, Collective Bargaining and Competition: The Application of Antitrust Standards to Union Activities, 73 YALE L.J. 14 (1963).

9. See, e.g., Connell Construction Co. v. Plumbers \& Steamfitters Local 100, 421 U.S. 616, 622 (1975). See also St. Antoine, Connell: Antitrust Law at the Expense of Labor Law, 62 VA. L. REV. 603, 604 (1976).

10. See J. Weistart \& C. Lowell, The Law of SPOrts 562-63 (1979).

11. See, e.g., NLRB v. Katz, 369 U.S. 736 (1962); NLRB v. American Mfg. Co., 351 F.2d 74 (5th Cir. 1965).

12. SeeH.K. Porter Co. v. NLRB, 397 U.S. 99, 107-08 (1970); NLRB v. Insurance Agents'Int'l Union, 361 U.S. 477, 487-90 (1960); Local 24, Int'l Bhd. of Teamsters v. Oliver, 358 U.S. 283, 295 (1959). See also H. Wellington, Labor and the Legal Process 49-125 (1968): Finkin, The Limits of Majority Rule in Collective Bargaining, 64 MINN. L. REV. 183, 196-98 (1980); Wellington, Freedom of Contract and the Collective Bargaining Agreement, 112 U. PA. L. REV. 467 (1964).

13. See generally J. Weistart \& C. Lowell, The LAW OF SPORTS 556-65 (1979).

14. The typical fact setting in which the labor exemption is tested occurs when a union attempts to raise the exemption defense. The defense may be asserted in an antitrust action brought by an employer whose employees are represented by the union, Local 189, Amalgamated Meat Cutters v. Jewel Tea Co., 381 U.S. 676 (1965), by a third party who alleges that its market activities are restrained, Allen Bradley Co. v. Local 3, IBEW, 325 U.S. 797 (1945), or by the government, United States v. Hutcheson, 312 U.S. 219 (1941). Where third parties' actions are involved, the employer may seek to join the union in claiming the protection of the exemption. 
ment collusion to control the entry of competitors and, ultimatelty, the price at which goods are sold. One of the teachings of the Supreme Court's treatment of the exemption question is that agreements which restrain third parties are suspect, and in their boldest forms will be found to be beyond the scope of the exemption. ${ }^{15}$ Qualitatively different, however, are the cases in which the agreed-upon restraint affects only the parties who participated in the bargaining relationship which produced it. ${ }^{16}$ At this point, concerns for conspiracy and collusion fade, and concern for encouraging robust bargaining predominates. Since the labor laws have the promotion of collective bargaining as a primary goal, and since present labor policy posits that such bargaining is best promoted by a minimum of judicial oversight of the substantive terms of any resulting agreement, labor contract terms which have purely intra-unit effects appear to present the most compelling case for foreclosing antitrust review. ${ }^{17}$

The restraints involved in the sports cases bear some resemblance to those that would be favorably viewed under the exemption. The relevant unit for collective bargaining includes all clubs within a particular league. ${ }^{18}$ Thus, a league-wide restraint, such as a compensation arrangement or a right of first refusal, only affects those within the bargaining unit. ${ }^{19}$ Third party and product market effects are generally not involved. Moreover, the subject matter of the restraints is intimately related to the employment relationship and appears to be the sort of issue that should be settled in collective bargaining. ${ }^{20}$ But the case for immunity for the restraints is not completed by these factors alone. Another critical issue concerns the degree of employee consent that will be required before the employer can claim the protection of the exemption. In the initial sports cases, the plaintiffs contended that although a collective bargaining relationship may have existed, the disputed restraints were thrust upon the player-employees and were not the product of a true agreement. ${ }^{21}$ Prior precedents provided little guidance on how this objection should be evaluated. The answers provided by the sports cases may be the most important contribution of these decisions. The development of that

15. See, e.g., Allen Bradley v. Local 3, IBEW, 325 U.S. 797 (1945). See also Leslie, Principles of Labor Antitrust, 66 VA. L. REV. 1183 (1980).

16. See, e.g., Local 189, Amalgamated Meat Cutters v. Jewel Tea Co., 381 U.S. 676 (1965). See also Note, Labor Exemption to the Antitnust Laws, Shielding an Anticompetitive Provision Devised by an Employer Group in Its Own Interest: McCourt v. California Sports, Inc., 21 B.C.L. REV. 680, 710 (1980).

17. See text accompanying notes $40-42$ infra.

18. See, e.g., North Am. Soccer League v. NLRB, 613 F.2d 1379 (5th Cir.), cert. denied, 449 U.S. 899 (1980).

19. Some earlier varieties of restraints had unmistakable effects on persons outside the bargaining unit. This was true, for example, of a reserve clause that gave a club perpetual claim to a player's services. Such a clause could impede the ability of a competing league to acquire the players necessary to offer a creditable sports product. See, e.g., Philadelphia World Hockey Club, Inc. v. Philadelphia Hockey Club, Inc., 351 F. Supp. 462 (E.D. Pa. 1972). See also text accompanying notes 31-34 infra. This type of arrangement is no longer used in the major professional leagues.

20. Litigation in the sports industry eventually produced a general agreement that the prevalent forms of player restraints were mandatory subjects of bargaining. See, e.g., McCourt v. California Sports, Inc., 600 F.2d 1193 (6th Cir. 1979); Mackey v. NFL, 543 F.2d 606 (8th Cir. 1976); Alexander v. NFL, 1977 2 Trade Cas. I 61,730 (D. Minn.), affd sub nom. Reynolds v. NFL, 584 F.2d 280 (8th Cir. 1978).

21. See, e.g., Mackey v. NFL, 407 F. Supp. 1000 (D. Minn. 1975), affd in part, rev'd in part, 543 F.2d 606 (8th Cir. 1976). See also Smith v. Pro Football, Inc., 420 F. Supp. 738 (D.D.C. 1976), affd, 593 F.2d 1173 (D.C. Cir. 1978). 
answer came quite slowly, however. A review of this development will indicate both the range of initial disagreement and the relationship between the inquiry into employee consent and the role of the courts in overseeing the collective bargaining process.

\section{A. The First Formulations}

Under what circumstances will antitrust immunity be extended to restraints which only have affects within the bargaining unit? One of the first considerations of this issue in the sports context was undertaken in an article published in 1971 by a Yale law student, Michael Jacobs, and his professor, Ralph Winter. ${ }^{22}$ The Jacobs and Winter thesis was that the controversy surrounding the player restraints was really not an antitrust concern at all, but rather was a matter for the labor laws. The authors found that devices such as the draft system and reserve clauses were mandatory subjects of bargaining and that each side had a duty to bargain that could be enforced through the National Labor Relations Board (NLRB). The article emphasized that the restraints had mainly intra-unit effects and thus did not seem to rise to the threshold of antitrust review suggested by the leading labor exemption precedents. ${ }^{23}$

The approach taken by Jacobs and Winter did not require that they give detailed treatment to the issue of the quality of employee consent required before the exemption would attach. However, their basic thesis has important implications for the current question. Jacobs and Winter suggest that the essential ingredients for the exemption are that the restraint be a mandatory subject of bargaining and that its primary effects be intra-unit. ${ }^{24}$ This formulation did not require that there be actual bargaining or employee consent before the hand of the antitrust court would be stayed. Rather, immunity was apparently to flow from the prospect of colllective bargaining, a prospect which was more than a mere potentiality because the labor laws imposed on each side an administratively enforceable duty to bargain.

This approach minimizes, almost to the point of preclusion, the role of antitrust courts in reviewing and evaluating the parties' collective agreement and the negotiations that precede it. The court hearing the antitrust complaint need not examine the labor contract or the exchanges which took place because these are irrelevant to the issue of the exemption. The only relevant questions, again, concern the characterization of the restraints as mandatory or permissive subjects of bargaining and the degree of impact on persons not within the bargaining unit. Neither issue should bring the court in conflict with labor policies favoring limited review of collective bargaining agreements.

The Supreme Court precedent relied upon by Jacobs and Winter did support the view that restraints which involved mandatory subjects of bargaining and which only affected unit employees were prime candidates for antitrust immu-

22. Jacobs \& Winter, Antitrust Principles and Collective Bargaining by Athletes: Of Superstars in Peanage, 81

YALE L.J. 1 (1971).

23. Id. at 26-28.

24. Id. 
nity. ${ }^{25}$ But the existing precedents could not be read as eliminating the requirement of actual employee consent. Indeed, the restraints that had been approved by the Court stood in a much different light. The affected employees had not only given their consent, but had actually first proposed the restraints and bargained for their adoption. ${ }^{26}$ It seemed unlikely that the Court would treat this feature of employee initiative as irrelevant.

The concern involved here can be illustrated by concrete cases. One is the situation in which the employer group imposes upon the union a restraint which was originally devised by the employers long before the union appeared on the scene. A new union that was only beginning its collective bargaining role might be so preoccupied by basic economic concerns that it gave no serious attention to the restraint and never engaged in bargaining over it. A variation of this scenario is one in which a strong, cohesive employer group is able to simply overpower an established, but weak union and exact not a consent, but what is at best a nonobjection to a restraint devised wholly unilaterally by the employers. ${ }^{27}$ Such a restraint might be no. different than one which would have been imposed if no collective bargaining relationship existed. If the restraint would be subject to antitrust review in the latter case, it might be questioned why the results should be different when the bargaining process is wholly ineffectual in altering the employer-devised proposal.

The specific concern in these cases is that a grant of antitrust immunity would move the labor exemption far beyond the legal policies from which it originated. The first formulations of the exemptions were unmistakably intended to protect union organizational activities and economic tactics ${ }^{28}$ Thus, classic strikes, boycotts and appeals to employees were removed from the purview of the antitrust laws. As the the labor movement matured and the emphasis shifted from organization to collective bargaining, it was realized that agreements as well as actions must be withdrawn from antitrust scrutiny. ${ }^{29}$ In each instance, the ultimate objective of the labor exemption was the same-the furtherance of employees' goals through collective action. ${ }^{30}$ In the cases described above, the notion of furthering

25. See, e.g., Local 189, Amalgamated Meat Cutters v. Jewel Tea Co., 381 U.S. 676 (1965). See also Note, Labor Exemption to the Antitnust Laws, Shielding on Anticompetitive Provision Devised by an Employer Group in Its Own Interest: McCourt v. California Sports, Inc., 21 B.C.L. REV. 680, 705 n.200, 710 (1980).

26. See Local 189, Amalgamated Meat Cutters v. Jewel Tea Co., 381 U.S. 676 (1965).

27. The Executive Director of the NFL Players Association, Ed Garvey, has expressed concern as to whether existing precedents would authorize judicial intervention in the situation in which a weak union is overpowered in the bargaining process. See note 57 infra.

28. See, e.g., Norris-LaGuardia Act, Pub. L. No. 65, § 4, 47 Stat. 70 (1932) (codified at 29 U.S.C. $\$ 104$ (1976)). See generally United States v. Hutcheson, 312 U.S. 219 (1941); Apex Hoisery Co. v. Leader, 310 U.S. 469 (1940); E. Berman, Labor and The Sherman ACT 3-54, 99-1 17 (1930).

29. See, e.g., Local 189, Amalgamated Meat Cutters v. Jewel Tea Co., 381 U.S. 676 (1965). See also Connell Construction Co. v. Plumbers \& Steamfitters Local 100, 421 U.S. 616, 622 (1975).

30. United States v. Hutcheson, 312 U.S. 219 (1941), had a significant effect in cementing the notion that the promotion of employee interests was a critical ingredient in the grant of the exemption. The Court in Hutcheson applied the exemption to insulate a union from liability for certain secondary boycott activities. In stating the conditions for the exemption, the Court emphasized that immunity was available "[s]o long as [the] union acts in its self-interest" and also does not conspire with non-labor groups. Id. at 232. Later cases recognized that agreements with employers did not transgress the second element mentioned. See, e.g., Connell Construction Co. v. Plumbers \& Steamfitters Local 100, 421 U.S. 616, 622 (1975); 
employee goals seems misplaced, for the employer is the only beneficiary of the exemption.

It was not long before the debate about the role of employee consent moved from the formative stage of the Jacobs and Winter article to the level of real world litigation. The first significant judicial pronouncement came in 1972 and set a tone which called for a more confined reading of the exemption. Philadelphia World Hockey Club, Inc. v. Philadelphia Hockey Club, Inc. ${ }^{31}$ was brought as an antitrust attack by the then recently formed World Hockey Association (WHA) clubs upon the allegedly monopolistic grasp which the established National Hockey League (NHL) held on hockey talent. The sources of the defendant's control over players were a draft arrangement and a reserve system which severely limited the players' ability to freely sell their services both within the league and without. The defendant league argued that since the restraints were employment terms and since a collective bargaining relationship existed between it and the affected player, immunity should follow. The district court rejected this contention, finding, among other things, that there never really had been any bargaining over the restraint. Judge Higginbotham's conclusion clearly implies that the mere potential for bargaining is not enough to produce immunity. The court was able to distinguish existing Supreme Court precedents involving the labor exemption. Judge Higginbotham noted that the term in question in those cases

pertained to issues which furthered the interests of the union members and on which there had been extensive collective bargaining. . . [T] hat is not true in this litigation. The National Hockey League has not come forward with any substantial evidence which could warrant this Court finding that the reserve clause . . . was ever a subject of serious, intensive, arm's-length collective bargaining. ${ }^{32}$

Rather, the reserve clause was found to be the product of unilateral employer action which predated the advent of collective bargaining, and which continued as a league practice even after the players' union was established.

The court did not need to define in detail the quality of consent which would be sufficient to produce immunity. The restraints involved in the case had another, more preliminary defect and that was that these effects were not merely intra-unit. Indeed, the plaintiff's main objection, which was substantiated by the evidence, was that the reserve system operated to prevent player movement to competing leagues. ${ }^{33}$ Because of this feature, and because the restraints were clearly employer-designed, the defendants' claim of immunity was not compelling. ${ }^{34}$

A subsequent case involving the National Basketball Association (NBA) pro-

Local 189, Amalgamated Meat Cutters v. Jewel Tea Co., 381 U.S. 676 (1965). And while the requirement of a pursuit of self-interest plays a less explicit role in recent decisions, it has not been abandoned. In the cases where the Court applied the exemption, there has not been a basis to doubt whether the employee interests were thereby promoted. See, e.g., Local 189, Amalgamated Meat Cutters v. Jewel Tea Co., 381 U.S. 676 (1965); Local 24, Int'l Bhd. of Teamsters v. Oliver, 358 U.S. 283, 294 (1959). See also St. Antoine, Connell: Antitrust Law at the Expense of Labor Law, 62 VA. L. REV. 603, 604 (1976).

31. 351 F. Supp. 462 (E.D. Pa. 1972).

32. Id. at $498-99$.

33. See id. at 510-11.

34. Jacobs \& Winter, Antitrust Principles and Collective Bargaining by Athletes: Of Superstars in Peonage, 81 YALE L.J. 1, 27-28 (1971). 
vided a clearer test on the critical issue of the degree of employee involvement necessary to produce immunity. In Robertson $v$. National Basketball Association, ${ }^{35}$ the defendant league attempted to secure judicial approval of the thesis that restraints with purely intra-unit effects should be regarded as raising only labor law concerns. The league's view was that a two-step test should be applied to determine the availability of the exemption:

The test for applicability of the labor exemption . . . is twofold: (1) Are the challenged practices directed against non-parties to the relationship; if they are not, then (2) are they mandatory subjects of collective bargaining? If the answer to No. 1 is no and to No. 2 yes, the practices are immune. . . . ${ }^{36}$

This formulation, like that of Jacobs and Winter, was an invitation to the courts to avoid any inquiry into the degree of employee acceptance of the disputed term. The premise of this view, again, is that judicial decisions in this area should be guided by the traditional labor policy of removing the bargaining process from judicial scrutiny except as is necessary to establish that the statutory duty to bargain has been met. ${ }^{37}$ This expansive interpretation was well suited to the position in which the Robertson defendants found themselves. The restraints in question there were largely the product of unilateral employer actions, and represented the continuation of practices begun long before the union came into existence.

The league's argument did not impress District Court Judge Carter, however. Nor was the judge prepared to search for subtle refinements of the league's proposed two-step inquiry. Indeed, it was Judge Carter's view that "[ $\mathrm{t}$ ] he test proposed by [the] NBA ha[d] no validity." 38 Not only could he find no support for it in the Supreme Court's labor exemption decisions, he also felt that the test asked the wrong question. In Judge Carter's view, 'The basic inquiry must focus on determining whether the controverted practices or regulations were in the union's own interest." 39 The Judge found it extremely difficult to believe that pervasive restraints on player mobility could ever have been seen by the union as being in its members' self-interest.

Judge Carter's opinion stands as evidence that courts were reluctant to embrace the expansive reading of the labor exemption proposed by Jacobs and Winter. However, the alternative view which it suggests is hardly satisfactory. Robertson implies that terms proposed by the union may be exempt while those originating with the employer will not. Such a rule would likely operate to encourage elaborate and intricate posturing by the employer to induce the union to make certain proposals which the employer desired. Thus, not only the substance of the proposal, but also the manner of its presentation would become mat-

35. 389 F. Supp. 867 (S.D.N.Y. 1975). Other aspects of the case are treated at 1975-2 Trade Cas. I 60,448 (S.D.N.Y.) (further preliminary motions); 72 F.R.D. 64 (S.D.N.Y. 1976), affd, 556 F.2d 682 (2d Cir. 1977) (review of class action settlement); 413 F. Supp. 88 (S.D.N.Y. 1976), affd, 622 F.2d 34 (2d Cir. 1980) (denying Wilt Chamberlain's right to pursue separate action against NBA); and 479 F. Supp. 657 (S.D.N.Y. 1979), aff'd in part, rev'd in part, 625 F.2d 407 (2d Cir. 1980) (review of compensation award to Seattle SuperSonics for loss of free agent, Marvin Webster, to N. Y. Knicks).

36. 389 F. Supp. at 886 (quoting NBA Memorandum at 28).

37. See notes 11-13 supra.

38. 389 F. Supp. at 889.

39. Id. 
ters to be arranged between the parties. This approach seems quite far-removed from the model of bargaining embodied in the labor laws. The mutual nature of the statutory duty to bargain and the law's general preference for freedom of contract suggest that the proposals of neither side are to be preferred.

\section{B. Refinement of the Grounds for Immunity}

Because the initial Robertson decision was not appealed, there was no occasion for correcting the misleading impression which it gave. However, at the same time as Robertson, the major professional football league was defending one of its own player restraints in Mackey v. National Football League. ${ }^{40}$ The Rozelle Rule, an arrangement for compensating clubs for the loss of a player signed by another team, provided the focus for the litigation. The case presented the first occasion for an appellate court to address the question of the threshold for the labor exemption. The test eventually announced by the Eighth Circuit incorporates the two-step inquiry advocated by the NBA in Robertson and originally suggested by Jacobs and Winter. The court went further, however, and added a critical third element which examines the quality of the union's assent to the term in question. In the court's view, a restraint, such as the Rozelle Rule, enjoys antitrust immunity if it

[f]irst . . . affects only the parties to the collective bargaining relationship . . . . [s]econd, ... concerns a mandatory subject of collective bargaining .... [and third] . . . is the product of bona fide arm's-length bargaining. ${ }^{41}$

By the time of Mackey, there was little room for disputing that the Rozelle Rule satisfied the first two elements. The rule had its main impact on the NFL players themselves, and because it so directly affected "conditions of employment," it appeared to be a mandatory subject of bargaining. ${ }^{42}$ The third requirement of bona fide arm's length bargaining required a more detailed review on the facts of Mackey.

The players' union and the NFL owners had entered into two collective bargaining agreements prior to the initiation of the Mackey litigation. In the negotiations preceding the first agreement in 1968, the player restraints received little attention. This was the first bargaining effort by the new union, and its relatively weak bargaining position apparently dictated that attention be focused on basic issues relating to compensation and pensions. The resulting collective bargaining agreement did incorporate the league constitution and by-laws, of which the Rozelle Rule was a part. ${ }^{43}$ The agreement also provided that rules on free agency would not be amended during the term of the labor contract. ${ }^{44}$ When this agree-

40. 407 F. Supp. 1000 (D. Minn. 1975), affd in part, rev'd in part, 543 F.2d 606 (8th Cir. 1976).

41. 543 F.2d at 614 (citations omitted).

42. Some earlier cases had disputed this conclusion. See Mackey v. NFL, 407 F. Supp. at 1009; Robertson v. NBA, 389 F. Supp. at 890 . However, it seemed undeniable that restraints such as the Rozelle Rule have an impact upon the conditions under which players are employed. Indeed, the restraints had long been objected to by the players unions, precisely because they were such an important term of employment. See also Jacobs \& Winter, Antitrust Principles and Collective Bargaining of Athletes: Of Superstars in Peonage, 81 YALE L.J. 1, 10-11 (1971). The fact that the unions objected to the restraints did not mean that they vigorously bargained against them. See text following this note.

43. 543 F.2d at 613.

44. Id. 
ment expired, the parties resumed negotiations and eventually signed a new agreement in 1970. The matter of player restraints again received little attention in the bargaining sessions, and the final agreement included no express reference to the Rozelle Rule. However, negotiators for both the owners and the players testified that it was understood that the restraint would continue in effect under the 1970 agreement. ${ }^{45}$ At the time of the Mackey decision, the 1970 agreement had expired and subsequent negotiations had not produced a new agreement. ${ }^{46}$ The court's characterization of the Mackey facts suggests that the case is one of a weak union mustering its limited strength to deal with a limited range of issues, mostly in the areas of pension and other economic benefits. It is suggested that the matter of the Rozelle Rule did not come within the union's narrow bargaining focus, and that the union did not resist the employers' efforts to continue its past practice. Thus, while there was a bargaining relationship between the parties, it was of a most preliminary sort. ${ }^{47}$ In the court's view, this was not sufficient to establish the bona fide arm's-length bargaining necessary to satisfy the third element of its test. The court seemed particularly influenced by the fact that the form of the restraint "[h]ad remained unchanged since it was unilaterally promulgated by the clubs in 1963." 48 The union's mere lack of resistance to the status quo did not constitute the type of consent which the court thought was required for immunity.

45. Id.

46. NFL management representatives contended that the presence of the Mackey litigation impeded the process of collective bargaining. See Oversight Hearings on National Football League Labor-Management Dispute: Hearings Before the Subcomm. on Labor-Management Relations of the House Comm. on Education and Labor, 94th Cong., 1st Sess., 51-55 (1975). See also Alexander v. NFL, 1977-2 Trade Cas. \ 61,730, at 72,997 (D. Minn.). Another view is that Mackey was necessary to remove an unfair bargaining advantage that the owners enjoyed as a result of their maintenance of illegal restraints. See J. WeISTART \& C. LOWELL, THE LAW OF SPORTS 586-88 (1979).

47. See text following note 42 supra.

48. 543 F.2d at 616.

An interesting question arises as to the availability of other grounds upon which a union might object to an employer's continuation of a player restraint devised before collective bargaining was initiated. A case of potential relevance is Morio v. North Am. Soccer League, 501 F. Supp. 633 (S.D.N.Y.), affd, 632 F.2d 217 (2d Cir. 1980). Among other things it was alleged that the NASL signed new individual player contracts and continued to enforce pre-existing contracts while under a duty to bargain with a newly formed players' union. The Regional Director of the National Labor Relations Board received complaints that these actions constituted unfair labor practices. In the present proceeding, the Regional Director petitioned the court for an order enjoining the enforcement of the individual contracts. The statutory basis for the request was section 10(j) of the Labor Management Relations Act of 1947 which empowers the Board to seek injunctions and other appropriate relief while its consideration of unfair labor practice charges is pending. See 29 U.S.C. $\$ 160(j)$ (1976). The district court issued an injunction against the enforcement of the individual contracts and this was affirmed on appeal.

The district court found that the individual contracts were "apparently" in violation of the employers' duty to bargain with the union. $501 \mathrm{~F}$. Supp, at 639 . With the individual contracts in place, the court observed, "[T] here simply is no incentive for Respondents to bargain with the Union . . . ." Id. at 640 . Hence, an injunction was issued. In affirming, the court of appeals adopted the lower court's findings and added that there was sufficient evidence that the league's practices were undermining the position of the union and might render ineffective the remedies eventually entered in the Board's unfair labor practice proceeding. 632 F.2d at 218.

An order such as that entered in Morio could have the effect of forcing the league to abandon the continuation of pre-existing player restraints. If the league members could neither enforce prior contracts nor sign new ones, there would be doubt as to the contractual basis for a club's invocation of a restraint. While the order actually entered in Morio specifically preserved the club's right to retain "exclusive rights" in a player, 501 F. Supp. at 639, this exception appears to be highly discretionary and its exact meaning 
There are several aspects of the Mackey case which are worthy of note. For one thing, Mackey implicitly rejects the approach to the labor exemption reflected in Judge Carter's opinion in Robertson. Judge Carter insisted that antitrust immunity would not be available unless some important employee interest was furthered. ${ }^{49}$ Mackey avoids that line of analysis and emphasizes instead that it is the nature of the bargaining which is relevant for exemption purposes, not the source of the proposal term or the structure of the debated provision. This approach seems sound, for if the requisite level of bargaining is found, it is unnecessary to ask the additional question of whether employee interests are furthered. In a bargaining relationship entitled to respect, the prevailing policy of freedom of contract dictates that the union be allowed to decide for itself how employee self-interest is best protected. ${ }^{50}$

Mackey thus made an important contribution by clarifying which of several potential issues was most critical in defining the threshold for the labor exemption. It is not the question of employee self-interest, or whether the terms agreed upon were reasonable compromises, but rather the quality of the employee's consent to the terms in question. ${ }^{51}$ As noted, the exemption, at least in the nonstatutory version applicable to the present problems, is premised on a policy of respect for collective bargaining. ${ }^{52}$ It is thus highly relevant to ask whether there has ever been an agreement on the disputed devices. The mere fact that there is a labor contract between the parties is not a guarantee that all aspects of their relationship are the product of consent. ${ }^{53}$

Although Mackey brings into sharper focus the central issue in the player restraint cases, the decision raises other questions which warrant attention. The concern for the quality of employee consent invites courts to sit in judgment of the collective bargaining process and the agreement that is reached. But what degree of judicial intervention is authorized? To what extent will the traditional labor

somewhat unclear. It is not obvious that it would insure the enforceability of all player restraints. It is not obvious, for example, that a draft system or requirements for free agent compensation would be protected.

To the extent that any restraints could be made unenforceable by a Morio-type injunction, the question arises as to whether the availability of such relief lessens the strength of the players' antitrust case. The argument could be made that during periods when the employer is unilaterally invoking pre-existing restraints, the labor laws and the remedies these provide should be given preemptive effect. Such a preference for the labor solution might be seen as consistent with the policies that give rise to the more common applications of the labor exemption.

49. See text accompanying note 39 supra.

50. See authorities cited in note 12 supra. See also Modjeska, Guess Who's Coming to the Bargaining Table?, 39 Оніо ST. L.J. 415, 432-35 (1978).

51. For a commentary that gives further attention to the role of employee self-interest in the definition of the availability of the exemption, see Note, Labor Exemption to the Antitust Laws, Shielding an Anticompetitive Provision Devised by an Employer Group in Its Own Interest: McCourt v. California Sports, Inc., 21 B.C.L. REV. $680,696-97$ (1980). The author of the note indicates some reservations about the Mackey court's refusal to give more emphasis to the need for agreements which promote employee interests. See id. at 704-06.

52. This point received particular emphasis by the court in Mackey. See 543 F.2d at 612, 613-14.

53. Another context in which there is reason to question the quality of the employees' consent involves cases in which it is alleged that the union is a creation of the employer and its collective bargaining agreement a sham. Some of these cases raise antitrust issues, typically when a complaint is brought by a rival, legitimate union. See International Ass'n of Heat \& Frost Insulators v. United Contractors Ass'n, 483 F.2d 384 (3d Cir. 1973); Carpenters District Council v. United Contractors Ass'n, 484 F.2d 119 (6th Cir. 1973). 
policies of freedom of contract be respected? The Mackey opinion has some notable implications on these points.

Mackey affords immunity only when the disputed term is the product of bona fide arm's-length bargaining. One passage of the opinion might be read as suggesting that a court is authorized to review in detail the negotiations which yielded the disputed term. The defendant league contended, in effect, that while the Rozelle Rule was largely the continuation of unilateral management practice of long standing, the defendant had bargained over this term and given a quid pro quo for its continuation. ${ }^{54}$ The alleged quid pro quo was increased pension benefits and the right of players to negotiate salaries individually. The court of appeals approved the district court's finding that there had been no such quid pro quo arrangement. ${ }^{55}$ That conclusion, however, presupposes that there was a careful review of what occurred at the bargaining table, and apparently such an examination had been undertaken. The court does not suggest any limit on the type of inquiry to be undertaken, and the opinion may be read to mean that the review is not to be confined. ${ }^{56}$ Relatedly, some may see the further implication that if a court finds an exchange, it is empowered to determine whether the union received "enough" for the concession it made. For example, what if the apparent quid pro quo for incorporation of pervasive restraints was the employer's agreement to a request by a weak union for a small adjustment in the player per diem expenses? Some might read Mackey as suggesting that the availability of immunity depends on whether a district court judge is satisfied that what was received by the union was fair value for what was given up. ${ }^{57}$

54. 543 F.2d at 616.

55. Id.

56. The court evaluated the league's evidence on the quid pro quo argument and found it lacking. See id. at 616 n.17. The unrestrained nature of the court's review again suggests that there is no substantive rule limiting the evidence to be considered and that had more evidence been presented, a more detailed appraisal would have been required.

57. Ed Garvey, Executive Director of the NFL Players Association, raised these same concerns in an article published after the Mackey decision. While Mr. Garvey advocated detailed judicial review of the bargaining process, he expressed doubts as to whether Mackey would be given such an expansive reading:

While some union advocates might feel elation at the sudden elevation of the union's role, the Eighth Circuit decision was indeed a mixed blessing. If the athlete is now denied access to the courts under the labor exemption theory, how is he protected if his union is overwhelmed by management? What if the union accepts the old baseball renewable option in return for increased pension money? In other words, what is the result if the union gives away player rights in exchange for pet projects of the leadership? What happens if the union is too weak to resist management's insistence on a restrictive reserve system?

The court has placed an enormous burden on the shoulders of the union, particularly when the union is bargaining with [twenty-eight] millionaires operating an unregulated monopoly. In effect, the courts have handed off the antitrust laws to the sports unions and left the stadium. They aren't even going to sit and watch the results.

The NFL Players Association argues that each restriction on the professional athlete must be examined on its own merits. The NFLPA does not believe that the old draft and the Rozelle Rule could be accepted as a quid pro quo for economic gain but that position is in some doubt. The Mackey court did not decide the quid pro quo issue but it would be difficult to believe that a court will go behind a collective bargaining agreement to determine whether or not there truly was good faith bargaining on a reserve system. The assumption will be that if it's in an agreement then the union accepted it in good faith.

Garvey, From Chattel to Employee: The Athlete's Quest for Freedom and Dignity, 445 AnNaLs 91,100 (1979). 
The prospect of courts engaging in qualitative appraisals of the terms of an exchange raises numerous problems. At the practical level is the question of whether the details of the bargaining process can ever be accurately reconstructed. Incomplete record keeping and an abiding tendency toward "posturing" make such reconstructions risky. ${ }^{58}$ Beyond that is the general problem that such inquiries run contrary to an otherwise well-entrenched general labor policy against subjecting collective bargaining to detailed scrutiny. ${ }^{59}$ If the premises of this policy are sound, the courts may find that the potential of their detailed review ultimately inhibits bargaining and deters peaceful resolution of labor disputes. These, of course, are the "horrors" which prompted some persons, including authors Jacobs and Winter, to define a threshold for the exemption which completely eliminated any appraisal of the nature of the bargain which had taken place. ${ }^{60}$

A review of earlier precedent established that the notion of bona fide arm'slength bargaining used by the Mackey court as a critical ingredient for immunity was not intended by other courts to authorize the sort of substantive appraisal of the parties' bargain that might be encouraged by Mackey. The bona fide arm'slength bargaining language can be traced back through earlier sports cases to the Supreme Court's decision in Local 189, Amalgamated Meat Cutters v. Jewel Tea Company. ${ }^{61}$ Jewel $T e a$ arose from the efforts of the butchers' union to impose certain marketing hours restrictions on grocery stores in the Chicago area. ${ }^{62}$ Several stores agreed to a rule requiring meat counters to be closed at 6 p.m., even in grocery stores that were otherwise open for business. Jewel Tea Company sought a modification of the rule because it desired to operate self-service meat counters in the evening. The union refused to vary the provision and threatened a strike. Jewel Tea Company at first capitulated and signed the pertinent multi-employer bargaining agreement. Later, however, the chain filed a suit attacking the arrange-

58. An interesting illustration of the collateral uses of collective bargaining terms and actions related thereto is found in Kansas City Royals Baseball Corp. v. Major League Baseball Players Ass'n, 532 F.2d 615 (8th Cir. 1976). The parties had included in their collective bargaining agreement a provision which recited that the agreement did not "deal with" the reserve system, even though the owners contended that the system continued in effect. Id. at 618 . It later became important to determine what was meant by the language used. One participant in the negotiations offered this explanation: "[T]his language was an ambiguous, intentionally ambiguous, compromise of a point that would give both parties an opportunity to get up before a Congressional Committee and argue whether or not something had been done in the area of the Reserve System . . . ." Id. at 628 .

Although it was recited that the agreement did not "deal with" the reserve system, this statement was not entirely correct. The matter was obviously discussed and language was included which settled the issue for at least the time being. Moreover, the language was acceptable because it allowed the two parties to maintain diametrically opposed positions in more public forums. In these cases, where the agreement is not a candid recitation of the parties' intentions, there is an exacerbation of the problem of potentially unreliable evidence of what happened during negotiations.

59. See note 12 supra and accompanying text.

60. See, e.g., Jacobs \& Winter, Antitrust Principles and Collective Bargaining by Athletes: Of Superstars in Peonage, YALE L.J. 1, 12-13 (1971).

61. 381 U.S. 676 (1965). It was Philadelphia World Hockey Club, Inc v. Philadelphia Hockey Club, Inc., 351 F. Supp. 462, 498 (E.D. Pa. 1972), which first used language from Jewel Tea incorporating the bargaining standard.

62. A detailed discussion of the law before and after Jewel Tea can be found in Meltzer, Labor Unions, Collective Bargaining, and the Antitnust Laws, 32 U. CHI. L. REV. 659 (1965). 
ment on antitrust grounds. The Supreme Court chose the case for one of its most significant labor exemption decisions and ultimately found the marketing hours restriction to be exempt. The Court identified the essence of the controversy before it in a passage of the opinion thought to have significance for the sports cases. In the words of Justice White:

Thus, the issue in this case is whether the marketing-hours restriction . . . is so intimately related to wages, hours and working conditions that the unions' successful attempt to obtain that provision through bona fide, arm's-length bargaining in pursuit of their own labor union policies, and not at the behest of or in combination with nonlabor groups, falls within the protection of the national labor policy and is therefore exempt from the Sherman Act. ${ }^{63}$

As an initial matter, Jewel Tea is of only limited value for the issue presented in a case such as Mackey. The restraint in Jewel Tea, unlike those litigated in the sports cases, had an unmistakeable impact on the employer's ability to market its products. ${ }^{64}$ Because the impact of this restriction extended well beyond the immediate bargaining unit, it touched more closely on traditional antitrust concerns and thus attracted more exacting antitrust scrutiny than should the restraints in the sports cases, which are more purely within the labor law sphere. ${ }^{65}$

But apart from that point, it is doubtful that Justice White intended his reference to bona fide arm's-length bargaining to announce the benchmark for granting antitrust immunity. A more accurate view of the case is that the Court was simply characterizing the nature of the bargaining which had taken place in Jewel Tea and was thus implicitly indicating that the facts before it raised no question about the quality of the union's endorsement of the restraint. Indeed, the restraint was a creation of the union and a product of its successful bargaining. ${ }^{66}$ We learn little from this situation that will help us decide cases in which the restraint is less identified with employee interests. Nor is there much evidence that the Court understood that it was weighing the delicate question of labor policy that would be involved in attempting to reenact the course of a prior negotiation on an employee-requested restraint. ${ }^{67}$ Again, the language chosen by the Court indicates that it was considering a much different question.

All of this suggests that the Mackey case snould not be overread. Neither the specific language of Mackey nor the cited precedents invite later courts to make a detailed appraisal of the fairness of any exchange which might have taken place. Mackey can be taken as holding only that on the facts before the court, there had been no exchange, no bargaining, and no consent. Mackey is thus properly read as a case in which the disputed restraint had not yet entered the sphere of collective

63. 381 U.S. at $689-90$ [emphasis added].

64. See Jacobs \& Winter, Antitrust Principles and Collective Bargaining by Athletes: Of Superstars in Peonage, 81 Y ALE L.J. 1, 24 (1971).

65. See Note, Labor Exemption to the Antitrust Laws, Shielding an Anticompetitive Provision Devised by an Employer Group in Its Own Interest: McCourt v. California Sports, Inc., 21 B.C.L. REV. 680, 710 (1980).

66. See note 30 supra.

67. Other factors bearing on the debate over the feasibility of reconstructing the details of prior negotiating sessions are raised in Bartlett-Collins Co., 237 N.L.R.B. No. 106, 1978 N.L.R.B Dec. I 19,539; Reed \& Prince Mfg. Co., 96 N.L.R.B. No. 850 (1951), enforced, 205 F.2d 131 (1st Cir. 1953); NLRB Gen. Counsel Q. Rep., [1978] 98 Lab. Rel. Rep. (BNA) 61, 63-64; Modjeska, Guess Who's Coming to the Bargaining Table?, 39 Oніо ST. L.J. 415, 423 (1978). 
bargaining. It was, of course, a potential subject of bargaining. But the union's presence indicated no greater employee approval of the restraint than existed when the employer first imposed it several years before.

\section{Implementation of the Mackey Test}

Some two years after Mackey the courts were presented with another test of the appropriateness of judicial inquiry into the details of the parties' bargaining history. The case, McCourt v. Califormia Sports, Inc. ${ }^{68}$ is notable for its seeming confirmation of some of the troublesome implications of Mackey. The courts that passed on the McCourt complaint involved themselves in rather detailed factual findings concerning the negotiations that produced the restraint in dispute. The case does not reach the wrong result, however, and its main difficulty is the message which it delivers with respect to the treatment of future controversies.

The restraint in McCourt originated in By-Law Section 9A of the league's governing document. The bylaw authorized free agency for players who had played out their options, but also provided for a compensation arrangement under which a club hiring a free agent had to make an equalization payment to the player's original employer. The payment could take the form of player contracts, draft choices, or cash. In the event that the two clubs could not agree, compensation was determined by an arbitrator, who was empowered to select only between the last offer of each side. ${ }^{69}$ The bylaw was unilaterally devised by management after the original reserve system was disapproved in Philadelphia World Hockey Club. ${ }^{70}$ Subsequent collective bargaining between the owners and the players led to inclusion of the bylaw, in unaltered form, in the league's labor agreement.

Plaintiff McCourt's complaint arose from the fact that his contract with the NHL's Detroit club was selected as the means of compensating the Los Angeles club for the loss of a free agent signed by Detroit. ${ }^{71}$ In McCourt's view, the NHL arrangement was quite similar to the NFL's Rozelle Rule condemned in Mackey. The main difference was that, in the absence of an amicable settlement by the clubs themselves, decisions on compensation were to be made by an independent arbitrator rather than the league president. This resemblance to the Rozelle Rule, and the fact that the bylaw was the unilateral creation of the club owners, prompted the district court judge to deny the applicability of the labor exemption and to declare the restraint illegal. This judgment did not stand, however. On appeal, a majority of the three-member Sixth Circuit panel found the bargaining between the league and the union sufficient to warrant antitrust immunity. This

68. 460 F. Supp. 904 (E.D. Mich. 1978), rev'd, 600 F.2d 1193 (6th Cir. 1979).

69. See generally J. Weistart \& C. Lowell, The LaW of SpORTs 514-16 (1979); Comment, The National Hockey League Reserve System: A Restraint of Trade?, 56 J. URBan L. 467, 473-76 (1979).

70. Philadelphia World Hockey Club, Inc. v. Philadelphia Hockey Club, 351 F. Supp. 462 (E.D. Pa. 1972). See text accompanying notes 31-34 supra.

71. The use of the contracts of existing players as "payment" in compensation arrangements has always been controversial. In an earlier case, the transferred player's objection prompted a court to enjoin the assignment of the contract. Bryant v. National Football League, Docket No. CV 75-2543 (C.D. Cal., July 30, 1975) (TRO granted), order dissolved, id. (C.D. Cal., Aug. 7, 1975). See also Los Angeles Times, July 26, 1975, Pt. III, at 1, col. 1; id., July 27, 1975, Pt. III, at 1, col. 2; id., July 31, 1975, Pt. III, at 1, col. 5; id., Aug. 2, 1975, Pt. III, at 1, col. 1; id., Aug. 5, 1975, Pt. III, at 1, col. 5. 
conclusion was not without its detractors, however. Among them was Chief Judge Edwards, who entered a long dissent. ${ }^{72}$

The district court and the majority of the Sixth Circuit panel accepted the general tests for the labor exemption proposed in the Mackey decision. As in Mackey, the critical question in $M c$ Court was whether the restraints in question were the product of bona fide arm's-length collective bargaining. It was on this point that the two courts differed. In finding the bargaining to be insufficient, the district court emphasized that the compensation rule was written into the collective bargaining agreement in language identical to that contained in the league-created bylaw and cited testimony of the union representative to the effect that the owners had made it clear that they regarded By-law $9 \mathrm{~A}$ as non-negotiable. ${ }^{73}$ The owners responded that even though the bylaw had been adopted by the union substantially unchanged, the union had received several concessions in exchange for their consent to the arrangement. These allegedly included increased pension benefits, continuation of individualized salary negotiations, and a share of the proceeds from a planned international hockey competition. ${ }^{74}$ However, the district court found-presumably as a matter of fact-that these concessions were not given for the union's agreement to By-Law 9A, but rather represented trade-offs on other matters. ${ }^{75}$ The district court indicated that it had before it a situation in which a nonnegotiated, employer-devised term had merely been inserted into a collective bargaining agreement "to give the impression" that it had been bargained for. ${ }^{76}$

On appeal, the Sixth Circuit, of course, had to work with the same facts as the lower court. Moreover, the appellate court was restrained by the traditional requirement of respect for the trial court's findings unless they are clearly erroneous. ${ }^{77}$ Nonetheless, the majority of the Sixth Circuit was drawn to a different conclusion on the quality of the parties' bargaining. ${ }^{78}$ The court first introduced a refinement of the legal standard to be applied. While accepting that the ultimate test was whether there was bona fide arm's-length bargaining, the court thought that the concept of bargaining must take account of labor law precedents that define when the statutory duty to bargain is satisfied. Particularly relevant, in the court's view, were labor cases recognizing that the duty to bargain does not obligate a party, such as the league in McCourt, to modify demands which it puts forth. A position on a particular issue may be adopted and firmly maintained if the proponent is prepared to continue to meet at the bargaining table, engage in dis-

72. 600 F.2d 1193, 1206-18 (6th Cir. 1979) (Edwards, C.J., dissenting).

73. 460 F. Supp. at 911 .

74. Id.

75. Id.: "We cannot find from this evidence that the increased pension benefits, the right for players to negotiate salaries and the right to share in the proceeds from international hockey competition are directly related to collective bargaining on bylaw $9 \mathrm{~A} . "$

76. Id. See text between notes 26-28 supra. See also text accompanying note 58 supra.

77. See, e.g., Zenith Radio Corp. v. Hazeltine Research, Inc., 395 U.S. 100, 123 (1969); United States v. United States Gypsum Co., 333 U.S. 364, 394-95 (1948); 9 C. Wright \& A. Miller, Federal PraCTICE AND PROGEDURE $§ 2585$ (1971).

78. The majority's treatment of the lower court's finding on the trade-offs in bargaining was a source of particular concern for dissenting Judge Edwards. See 600 F.2d at 1213-14. 
cussions, and reach accommodations on other matters. ${ }^{79}$ The court quoted with approval the view of the Fifth Circuit that "[i]f the insistence is genuinely and sincerely held, if it is not mere window dressing, it may be maintained forever though it produce[s] a stalemate."80

This precedent allowed the Sixth Circuit to take a different view of the facts indicating that the owners had refused to accept modification of By-Law 9A. It was the majority's view that "[c]ontrary to the trial judge's conclusion, the very facts relied upon by him . . . illustrate a classic case of collective bargaining in which the reserve system was a central issue." 81 What the trial judge saw as unilateral employer action, and an overriding of employee will, the Sixth Circuit saw as merely rigorous bargaining. Thus the court noted that the union had invoked the standard bargaining tools-a threatened strike, refusals to attend bargaining sessions, threatened litigation-but was simply unsuccessful. ${ }^{82}$ In the majority view, the employer was not intransigent, however, for it made concessions on matters other than the disputed bylaw.

A significant impediment to the appellate court's characterization was the explicit finding by the trial judge that employer concessions on several matters, including pension benefits, individual salary negotiations, and a share of the proceeds of a planned international competition, were not a quid pro quo for the players' assent to the compensation arrangement. The normal rules of appellate review did not allow the court merely to declare the trial court to be in error on this point. Hence, another tack was necessary if the finding was to be avoided. The approach apparently selected by the appellate court was to ignore the lower court's contrary finding and to list a number of concessions made by the employers to preserve their version of the compensation arrangement. Indeed, in a somewhat innocuous footnote, the appellate court sets forth a list of benefits received by the players for their assent to the bylaw that includes not only the three rejected by the district court, but also seven others not mentioned by the lower court. ${ }^{83}$ Thus what the district court had seen as an absence of bargaining was resurrected as bargaining rigorous enough to satisfy the threshold of the labor exemptions. ${ }^{84}$

The majority's opinion makes a notable contribution to the labor exemption

79. See generally R. Gorman, Basic Text on Labor LaW: Unionization and Collective BaRGAINING 481-89 (1976). See also note 86 infra.

80. 600 F.2d at 1201, citing NLRB v. Herman Sausage Co., 275 F.2d 229, 231 (5th Cir. 1960).

81. Id. at 1202

82. Id.

83. Id. at n. 12:

Mr. Eagleson, the Executive Director of the NHLPA, testified that the union agreed to the provisions of By-Law Section 9A in return for many player benefits. In addition to the benefits described in the district judge's opinion, our review of the record indicates that the players bargained for substantial benefits: (1)increased pension benefits; (2) increased bonus money to players on teams finishing high in their divisions and participating in the Stanley Cup Playoffs; (3) sharing with the owners receipts from international hockey games; (4) greater salary continuation for players injured as a result of playing hockey; (5) increased training camp expense allowances; (6) modification of NHL waiver procedures; and (7) modification in scheduling of games and travel during the season.

84. Dissenting Judge Edwards was clearly not enamored by the Sixth Circuit majority's willingness to give a different characterization to the factual findings of the trial court. Judge Edwards found no extraordinary feature in the trial court record which impugned the findings as clearly erroneous. Id. at 1214,1218 . The dissent went further and suggested that the majority's grant of immunity was unprece- 
precedent by its firm suggestion that the mere fact that a collective bargaining term was originally devised unilaterally by management should not, in itself, be a reason for withholding immunity. It is understandable that a players' union which might ultimately agree to some form of restraint would be hesitant to assume a leadership role in propounding and promoting one particular version. There are good political reasons why union leadership would not want to appear to be advocating that players give up their mobility. More palatable is a position by the leadership that it used the employer's desire for a particular type of restraint as a lever to pry out major concessions on other matters.

The general point to be drawn here is that any regulation in this area must take account of the tremendous capacity of management and labor to mask their true intentions as they proceed through collective bargaining. ${ }^{85}$ One implication of the district court's approach is that the court might have viewed the matter differently if the league had started from a negotiating position which demanded a restraint much more severe than By-Law 9A and then "allowed" itself to be bargained down to a rule which incorporated By-Law $9 A$ provisions. ${ }^{86}$ In such a process, the employer would be well-advised to link each step to a union concession on some other point, which in itself may have begun from an inflated position. But a legal standard which expects great refinement and detailed exchange in collective bargaining will be too subject to manipulation. Thus, we should agree with the appellate court that it is not troublesome that the final version of the agreed-upon restraint was the product of the employers' hands and was unchanged from the earliest proposal. ${ }^{87}$

There are other aspects of the McCourt opinions which require a more critical appraisal, however. Both the district court and the Sixth Circuit assume that it is appropriate to make the availability of the labor exemption dependent upon the outcome of a detailed factual inquiry into the bargaining that took place between the parties. The appellate court was as interested as the district judge in the specifics of the bargaining process; it simply thought that these details supported a different conclusion than that reached in the initial proceeding. ${ }^{88}$ There are at least two difficulties with this approach. One has been previously mentioned and concerns the fact that there are serious limitations on the quality of evidence which can be produced on the nuances of the bargaining. ${ }^{89}$ The reliability of relevant

dented and unwise. In Judge Edwards' view, employer cartel activity ought not to be immunized simply because its authorization is incorporated in a collective bargaining agreement.

85. See notes 58-59 supra and accompanying text.

86. The technique appraised here is to be distinguished from the type of "take-it-or-leave-it" bargaining that is known as Boulwarism. Boulwarism occurs when the employer commences negotiations by announcing its "fair and firm offer" through a massive publicity campaign directed at the employees and the general public. This strategy functions to circumvent the union and it forces the employer to adhere to its initial offer in order to avoid embarrassment. This strategy was held to be illegal in NLRB v. General Electric Co., 150 N.L.R.B. No. 36, 1964 N.L.R.B. Dec. ๆ 13,651, enforced, 418 F.2d 736 (2d Cir. 1969), cert. denied, 397 U.S. 965 (1970). See generally R. Gorman, Basic TEXT ON LABOR LAW: Unionization and Collective Bargaining 383, 486-88 (1976).

87. See 600 F.2d at 1202 .

88. See notes 58,67 supra and accompanying text.

89. Bartlett-Collins Co., 237 N.L.R.B. No. 106, 1978 N.L.R.B. Dec. I 19,539; Reed \& Prince Mfg. Co., 96 N.L.R.B. No. 850 (1951), enforced, 205 F.2d 131 (1st Cir. 1953). 
evidence is undermined by the informality of the proceedings and the fact that they may be carried on at several different levels, both outside and within the bargaining room. Moreover, not only is a transcript not required, a party concerned about the future uses of the bargaining history may well commit an unfair labor practice.if it requests such transcription. ${ }^{90}$ One of the reasons given by the National Labor Relations Board for its stringent policy on this point is a desire not to make the parties accountable for all that is said at the bargaining table. ${ }^{91}$ Such a view is hardly compatible with a legal standard which causes multi-million dollar antitrust liability to turn on the specifics of the negotiations. ${ }^{92}$

The issue of the reliability of the evidence looms large in McCourt. The legal outcome is determined by whether the union's acquiescence to the restraint was given in exchange for substantial employer concessions on other matters, as the appellate court concluded, or whether it bore no relation to these concessions and was no more than the product of the overriding will of the employer, as the district court indicated. One does not come away from the two opinions with great confidence that one factual reconstruction of what actually happened is better than the other. ${ }^{93}$ What may be more believable is that bargaining is a dynamic process, and it is often difficult to tell what really produced a particular set of terms.

A second problem with the approach taken in the McCourt decisions is that it can undermine significantly the finality of the collective bargaining agreement. A desire for conclusiveness in labor negotiations is an important ingredient in the general policy of limiting judicial review of collective bargaining agreements. It is perceived that the availability of extensive post-agreement review will likely undermine the parties' willingness to bargain. ${ }^{94}$ The possibility that a concession achieved will later be thrown out by a court will lessen the beneficiaries' inclina-

90. See NLRB Gen. Counsel Q. Rep., [1978] 98 Lab. Rel. Rep. (BNA) 61, 63-63; Modjeska, Guess Who's Coming to the Bargaining Table?, 39 OHIO ST. L.J. 415, 416-17 (1978).

91. See, e.g., Carpenter Sprinkler Corp., 238 N.L.R.B. No. 139, 1978-79 N.L.R.B. Dec. If 15,065, at 28,234 (1978).

92. There are some situations in which the imperfect evidence of the parties' negotiating history must be considered if the purposes of the Act are to be fulfilled. This is true, for example, where there is a question as to whether a party fulfilled its duty to bargain in good faith. See Modjeska, Guess Who's coming to the Bargaining Table?, 39 OHIO ST. L.J. 415, 420-21 (1978). The fact that consideration of such evidence is necessary in some situations is, of course, not a concern for its use in other settings. Indeed, it would seem reasonable to suggest that in deciding the weight to be accorded such evidence, a legal system may properly take account of the magnitude of the substantive issue which will be affected by the evidence. The consequence of finding a lack of good faith in bargaining is relatively mild. Often the offending party is simply ordered to resume bargaining. Other issues, such as the availability of antitrust immunity, are potentially much more significant. The evidence of this in the sports area is the dramatic increase in the players' mobility and salary following the judicial rejection of claims of immunity. See, e.g., Alexander v.. NFL, 1977-2 Trade Cas. \$61,730, at 72,997-98 (D. Minn.), affd sub nom. Reynolds v. NFL, 584 F.2d 280 (8th Cir. 1978) (discussion of monetary settlement and new mobility rules prompted by Mackey decision).

93. One student commentator who has written on the case has concluded that the factual question of whether there was an exchange is indeed a close one. See Comment, The National Hockey League Reserve System: A Restraint of Trade?, 56 J. URBAN LAw 467, 496 (1979). It is also suggested that the court of appeals may not have considered all the facts relevant to.its ultimate conclusion that there was a quid pro quo relationship between the restraint and other benefits. Id.

94. See NLRB v. Insurance Agents' Int'l Union, 361 U.S. 477, 485-88 (1960); NLRB v. Jones \& Laughlin Steel Corp., 301 U.S. 1, 45 (1937). See generally H. Wellington, Labor and the Legal ProCESS 26-30, 49-63 (1968). Compare Jacobs \& Winter, Antitrust Principles and Collective Bargaining by Alhletes: Of Superstars in Peonage, 81 YALE L.J. 1, 12 (1971). 
tion to give a significant exchange. The ultimate horror would be a judicial order invalidating one part of a bargain, such as an agreement on player restraints, but continuing enforcement of expensive economic benefits, given to induce the concession.

The preference for finality has not meant that judicial review is to be entirely foreclosed. Such an absolute policy would invite the frustration of significant national policies ranging from those seeking to insure equal employment opportunity to those designed to disapprove illegal business combinations. ${ }^{95}$ But even on this point, the desire to maximize the meaningfulness of the negotiations can have a significant impact. Respect for this policy may limit occasions for judicial inquiry or operate to confine the review that is actually undertaken. ${ }^{96}$ A notable implication for our present purposes is that exceptions to the basic policy should be defined by resort to standards which insure a degree of predictability.

It is questionable whether the McCourt approach shows adequate sensitivity to these concerns. McCourt deals with the "exception" to nonreviewability which is made for violations of the antitrust laws. McCourt implicitly addressed the critical question of the conditions which will authorize judicial forays into consummated agreements. McCourt seems to assume that such a review is authorized anytime competitive violations are alleged. And the data to be appraised, of course, includes any evidence which contributes to a reconstruction of the bargain and an identification of the resulting exchange. ${ }^{97}$ While an exception to nonreviewability is needed, the legal system should prefer one utilizing standards which more carefully relate the occasions of judicial review to the likelihood that the complaining party will ultimately be successful when it breaches the veil of immunity. If good predictors of effective consent could be found, not only would some allegiance to the policy of finality be introduced, but also resort to unreliable evidence would be avoided.

\section{A Proposal: A Presumption of Consent}

Mackey and McCourt were indeed on the right track in suggesting that the quality of employee consent is important in appraising the respect to be accorded to the collective bargaining agreement. What is needed, however, is a different vehicle for identifying the collective agreements to be respected. The search for a different standard of review can properly proceed from the premise that the details of the actual bargaining may be less important than the quality of the collective bargaining relationship which exists between the parties. If the parties to the disputed agreement have a long-standing and well-established bargaining relationship_-if they have been through numerous agreements and each indicated a

95. See, e.g., Allen Bradley Co. v. Local 3, IBEW, 325 U.S. 797 (1945). See also text accompanying notes 8-13 supra.

96. See Wellington, Freedom of Contract and the Collective Bargaining Agreement, 112 U. PA. L. REV. 467, 471-74 (1964).

97. While $\mathrm{McC}$ Court is the first court to make a detailed appraisal of the parties' exchange in assessing the availability of the labor exemption, at least one other court seems to have accepted this technique. See Alexander v. NFL, 1977-2 Trade Cas. If 61,730, at 73,001 (D. Minn.), affd sub nom. Reynolds v. NFL, 584 F.2d 280 (1978). 
willingness to settle matters through collective bargaining-it is difficult to imagine the justification for questioning the effectiveness of either side's consent to a particular term in a particular negotiation. ${ }^{98} \mathrm{~A}$ history of strong bargaining should carry its own indicia that the rights of employees are not being subverted. ${ }^{99}$ It is a virtual tautology that a strong union which consents to a contract term has not been subjected to overreaching by the employer. Strong evidence of collusion should be required before the affirmation by a stable union is avoided. ${ }^{100}$

A significant attraction of evaluating the nature of the parties' relationship rather than the details of their bargain is that the relevant evidence does not share the defects of the proof required by the McCourt approach. The length of the parties' relationship, the substantiality of their contract terms relative to those prevailing elsewhere, and the durability of prior agreements are more susceptible to external, objective proof. While other more subjective data may also be relevant, the objectively demonstrable aspects of the relationship should serve as a check against unwarranted or misguided inferences.

In some cases, of course, the relationship between the union and the employer does not warrant the presumption of consent which is suggested here. Two classes of cases will be especially suspect. One involves newly formed collective bargaining relationships. Seldom does the union in this situation enter bargaining with the same authority enjoyed by those who have represented the employer's workers through numerous contracts. Nor are energies expended with equal force among various collective bargaining terms. Wages, pensions, and other economic benefits are likely to receive the union's first focus rather than the work rules typically involved in antitrust challenges. If the union itself is a new creation, the restrictive nature of the initial bargaining is likely to be exacerbated.

The other class of cases warranting closer scrutiny are those in which there is evidence that the strength of a formerly secure union has been eroded. A significant drop in support for the union, whether manifested by a decrease in membership or the advent of significant internal political factions, warrants a softening of

98. Professor Wellington has considered the relationship between judicial scrutiny of traditional contracts and the level of review afforded labor agreements. He identifies the element of the relative inequality of the parties' bargaining power as the factor that may explain the more ready judicial regulation of traditional contracts. See Wellington, Freedom of Contract and the Collective Bargaining Agreement, 112 U. PA. L. REV. 467, 494-98 (1964).

99. The notion that consent should be presumed gains some support from the frequently accepted view that one purpose of the Wagner Act, through its duty to bargain and protection of collective activity, was to "create aggregations of economic power on the side of employees . . . ." Cox, The Duty to Bargain in Good Faith, 71 HARV. L. REV. 1401, 1407 (1958). Many would assume that this effort was normally successful in imbuing the union with the requisite strength to deal effectively with the employer. See Wellington, Freedom of Contract and the Collective Bargaining Agreement, 112 U. PA. L. REV. 467, 497 (1964). Thus, only truly exceptional cases would give rise to concerns as to whether the union's consent satisfied the minimum level of voluntariness.

100. A similar question is the standard of proof required before a court will disregard an apparent labor agreement which is alleged to be a sham. See International Ass'n of Heat \& Frost Insulators v. United Contractors Ass'n, 483 F.2d 384 (3d Cir. 1973); Carpenters District Council v. United Contractors Ass'n, 484 F.2d 119 (6th Cir. 1973). See also Tugboat, Inc. v. Mobile Towing Co., 534 F.2d 1172 (5th Cir. 1976). In this context, it appears that courts frequently focus on the nature of the relationship between the employer and the union. A central question is whether the union was improperly dominated by the employer. See Carpenters District Council v. United Contractors Ass'n, 484 F.2d at 121. 
the presumption of consent. Closer attention to these cases will serve as some check against the employer's using a union's extreme vulnerability to impose terms which would not otherwise receive approval. ${ }^{101}$

The above division of cases is made with due regard for developments in the sports industry. Indeed, the proposal for sensitivity to recently formed collective bargaining relationships is intended to approve the approach taken in Mackey. The evidence in that case suggested rather strongly that the bargaining relationship was still very much in its developmental stages and had not matured to the point that a court could have confidence that all terms had a reasonable prospect of appearing on the bargaining table. ${ }^{102}$ The court's further inquiry into the actual bargaining process confirmed that there was no real consent. Other cases can be read as presenting features which similarly fall within the exception identified above. ${ }^{103}$

Does McCourt represent the first of the sports cases which should have been treated under the presumption of the consent? There are some objective features of the relationship which support that conclusion: the parties had been through several bargaining sessions; ${ }^{104}$ the disputed restraint occupied a prominent position in the resulting agreement; 105 the particular form of restraint was not of long standing; ${ }^{106}$ and unlike some other players' unions, that representing the hockey players in McCourt appears to have enjoyed good support among its constituency at the time of the negotiations. ${ }^{107}$ But the ultimate conclusion on this matter must remain somewhat in doubt because the record in McCourt was not developed for the purpose of addressing it. What can be suggested is that while McCourt was correct to embrace the point made in Mackey that consent was a critical issue, it does not follow that the McCourt facts required the same sort of detailed inquiry into what happened at the bargaining table. Unlike Mackey, McCourt did not raise significant preliminary doubts about the effectiveness of the union's bargaining. It would have been appropriate for the McCourt court to pause first to ask whether there were grounds to suspect that the players' apparent consent was not effective.

101. The Executive Director of the NFL Players Association has expressed concern about the availability of the labor exemption where the union involved is weak or misdirected by its leadership. More details of Mr. Garvey's views are set out in note 57 supra. He apparently would endorse a legal standard which encouraged judicial review in every case in which an agreed-upon restraint was contested.

102. See text accompanying notes 47-48 supra.

The district court in Mackey made specific detailed findings indicating the weak bargaining position in which the NFLPA found itself. See 407 F. Supp. at 1010.

103. See, e.g., Smith v. Pro Football, Inc., 420 F. Supp. 738 (D.D.C. 1976), affd, 593 F.2d 1173 (D.C. Cir. 1978); Philadelphia World Hockey Club, Inc. v. Philadelphia Hockey Club, Inc., 351 F. Supp. 462 (E.D. Pa. 1972).

104. Some of the early history of the parties' collective bargaining relationship is documented in Philadelphia World Hockey Club, Inc. v. Philadelphia Hockey Club, Inc., 351 F. Supp. 462, 481-86 (E.D. Pa. 1972).

105. Compare Mackey v. NFL, 543 F. 2d 606, 613 (8th Cir. 1976) (the most recent collective bargaining agreement failed to mention the restraint in question).

106. See text accompanying notes 69-70 supra.

107. See Letter from S.G. Simpson, NHLPA Director of Operations, to June C. Hubbard (June 18, 1981) (100 percent membership); Sporting News, Sept. 20, 1975, at 47, col. 1. Cf. N.Y. Times, Feb. 5, 1980, at C19, col. 3 (420 members in NHLPA); Province (Vancouver), Sept. 26, 1978, at 18, col. 3 (NHLPA upset with McCourt's challenge to section of collective bargaining agreement). 
The analysis suggested above should limit to a few extreme cases the need for a court to probe beyond a general appraisal of the parties' bargaining relationship. But even when such a case arises, the court should use care in selecting the evidence upon which it relies. To be avoided are decisions which find their ultimate support in highly impressionistic appraisals of a distant series of negotiations. On the other hand, it may be inevitable that there will be cases in which it is necessary to inquire as to exactly how much a particular issue was discussed and in. what terms. ${ }^{108}$ The credibility of any such investigation will depend upon the availability of some external evidence which supports the conclusion reached. A systematic approach to dealing with conflicting evidence would begin with an appraisal of the objective evidence and then probe the less reliable data to determine if it persuasively indicates a contrary view. Weight should be given to the impressionistic evidence only if its implication is unmistakable. In short, it should be treated as evidence of a different, and inferior, quality and its use should be circumscribed.

The most important implication in the above analysis goes not to refinements in the use of evidence, but rather to the limited significance of the cases decided to date. Cases such as Philadelphia World Hockey Club, Robertson, and Mackey should not be taken as an authorization for courts to undertake a detailed review of intraunit restraints found in collective bargaining agreements. These cases arose only because the respective collective bargaining relationships were quite new, and thus there was reason to doubt whether the restraints in question had been affected by the union's presence. The approach suggested above should operate to preclude this inquiry once the bargaining relationships have matured. Presumably the players' union's continued involvement in bargaining, and the parties' movement through successive agreements, will serve as evidence that this has occurred. Thus, the litigation to date may be largely of historical interest. Those cases that involve new unions launching new bargaining relationships should not be overread as an invitation for courts to treat each successive bargaining agreement as the occasion for a detailed appraisal of the bargaining which preceded it.

\section{Further Issues in Judicial Oversight of The Collective BARgaINING PROCESS}

One fundamental premise of the preceding analysis is that courts have limited authority to review the substantive terms of collective bargaining agreements. Federal labor policy accepts that the prevailing principle should be freedom of contract: the parties can agree to whatever terms they wish, and courts will not inquire into the wisdom or reasonableness of the bargain struck. This theme appears repeatedly in the decided cases, and its bases and implications have been

108. There are other contexts in which it becomes important to recreate the parties' negotiations. The fact that some such inquiries are made is not a justification for sanctioning general inquiries into bargaining history. See note 92 supra. Indeed, even where efforts to recreate negotiations are made at present, concerns arise for the quality of proof available. See Modjeska, Guess Who's Coming to the Bargaining Table?, 39 Оніо ST. L.J. 415, 420-21 (1978). 
the subject of several commentaries. ${ }^{109}$ The competing policies underlying the antitrust laws represent an exception to the general policy of judicial restraint, ${ }^{110}$ but it has been suggested above that as to contract terms with only intra-unit effects, the antitrust "exception" is limited to rare cases involving incomplete or defective bargaining relationships. For most situations, the larger policy of not second-guessing the parties' agreement will prevail.

While these policies are firmly embedded in the federal labor law, there is another phase of the player restraint litigation which might invite their evasion. To date, the potential for conflict between the labor law and class action rules is only suggested in the cases, and any apparent undermining of federal labor policy can be explained. The existing precedents are easily misread, however, and it seems useful to indicate how some of their broader implications should be confined.

The two noteworthy cases are Robertson v. National Basketball Association, ${ }^{11}$ one aspect of which was previously discussed, ${ }^{112}$ and Alexander $v$. National Football League ${ }^{113}$ which was an outgrowth of the Mackey case. The Mackey litigation was begun by' a group of named plaintiffs to attack the player restraints utilized in the NFL. Following the Eighth Circuit decision in Mackey which found the restraints to violate the antitrust laws, ${ }^{114}$ Alexander was initiated as a class action to seek damages and other relief for all existing and former NFL players. ${ }^{115}$ Both the Robertson and the Alexander class actions produced settlements. The respective players' unions were involved in each settlement arrangement. Either as a part of, or at least concurrent with, the resolution of the class action, a labor agreement was signed. ${ }^{116}$ The respective litigation settlements were later subjected to court review, as is required by relevant federal procedure. The treatment of the collective bargaining agreement differed in each review. But the respective courts chose to evaluate the settlement agreements under the legal standard applied to class action settlements generally. ${ }^{117}$ Thus, as perceived by Judge Carter in Robertson, " $[\mathrm{t}]$ he function of the court is to canvass the relevant factors necessary to render an informed judgment as to the faimess, reasonableness, wisdom and adequacy of the

109. See notes 12,50 supra and accompanying text.

110. See text accompanying notes 12-13, 95-97 supra.

111. 72 F.R.D. 64 (S.D.N.Y. 1976), affd, 556 F.2d 682 (2d Cir. 1977) (class action settlement).

112. See notes 35-39 supra and accompanying text (discussion of preliminary rulings on labor exemption and substantive antitrust claims). 1978).

113. 1977-2 Trade Cas. I 61,730 (D. Minn.), affd sub nom. Reynolds v. NFL, 584 F.2d 280 (8th Cir.

114. 543 F.2d 606 (8th Cir. 1976).

115. In later proceedings, the case became recaptioned as Reynolds $v$. NFL, reflecting the fact that only a few class members appealed the district court's decision approving the class action settlement. See 584 F.2d 280 (8th Cir. 1978).

116. See In re Robertson Class Plaintiffs, 479 F. Supp. 657, 663-64 (S.D.N.Y. 1979), affd in part, rev'd in part, 625 F.2d 407 (2d Cir. 1980); Alexander v. NFL, 1977-2 Trade Cas. at 72,985; Robertson v. NBA, 72 F.R.D. at 66-67.

117. See generally In re Beef Industry Antitrust Litigation, 607 F.2d 167, 179 (5th Cir. 1979); In re General Motors Corp. Engine Interchange Litigation, 594 F.2d 1106 (7th Cir.), cert. denied, 444 U.S. 870 (1979); Young v. Katz, 447 F.2d 431, 433 (5th Cir. 1971); 7A C. Wright \& A. Miller, Federal PracTICE AND PROCEDURE $§ 1797$, at 229 (1972); McGough \& Lerach, Termination of Class Actions: The Judicial Role, 33 U. PITT. L. REv. 445, 458 (1972). 
proferred termination of the action."118 Such an exacting standard of review hardly seems to incorporate the notions of freedom of contract and judicial restraint which apply under the labor laws. ${ }^{119}$ Indeed, the courts here thought themselves empowered to evaluate not only the reasonableness of the settlement, but also its adequacy. The question to be posed is whether this shift from a standard of judicial non-intervention to one of direct and detailed judicial review can be reconciled with the policy of restraint which predominates in the labor area. The degree of union involvement in the settlement is certainly relevant, as is the specific nature of the issues which are settled. The cases decided to date do not deliver clear pronouncements on the larger point, but an analysis of the decisions does provide the occasion for clarification.

\section{A. First Principles: The Case for Supplanting Class Action Review}

There are some situations in which the predominance of labor law policies ought to be clear. A brief review of a hypothetical case may be useful as a benchmark for evaluating the situations which have been litigated. The hypothetical case had these features: a group of players, with independent counsel and no obvious connection with the players' union, brings a class action alleging that the defendant league's player restraints violate the antitrust laws. The restraints in operation at the time of the litigation were devised by the defendant long before the union came into being. Further, we will assume that they had never been treated seriously in collective bargaining. The plaintiff-players seek relief for both prior injuries and those anticipated in the future. Thus, they seek money damages and an injunction. Assume further that later, the union and defendant employers independently enter into a collective bargaining agreement which modifies the future application of the restraints.

It should be clear that if the collective bargaining satisfies the threshold discussed in the first part of this paper, neither the class representatives nor their counsel could object to the terms of that labor contract on nonlabor grounds. The reason why that objection is removed is analytically significant. In particular, the union-employer agreement is not to be viewed as a "settlement" of the plaintiffs' case. Rather, the effect of the agreement is much more basic: it eliminates the plaintiffs' cause of action as far as prospective violations are concerned. Thus, the plaintiffs have not "lost control" of their cause of action. Rather, there is no cause of action for the now-immunized rules on player mobility. The new arrangement is a labor contract and should be accorded the same deference shown to other collective bargaining agreements; and the prevailing principle should be one of judicial restraint. ${ }^{120}$

The above analysis has implications for cases in which the union operates in

118. 72 F.R.D. at 68 [emphasis added]. See also Alexander v. NFL, 1977-2 Trade Cas. at 72,992-93.

119. "Within the area in which collective bargaining was required, Congress was not concerned with the substantive terms upon which the parties agreed. The purposes of the Acts are served by bringing the parties together and establishing conditions under which they are to work out their agreements themselves (citations omitted)." Local 24, Int'l Bhd. of Teamsters v. Oliver, 358 U.S. 283, 295 (1959).

120. It can be assumed that in the normal case, Mackey's three criteria for application of the labor exemption would be met. See text accompanying notes 40-43 supra. 
closer cooperation with the class representatives. The filing of the class action does not relieve the union, or the employer, of its duty to bargain about the terms and conditions of employment. ${ }^{121}$ The bargaining relationship continues and presumably could yield an agreement. ${ }^{122}$ Where that happens, the agreement is again not merely a "settlement of the pending litigation." It is, rather, the expected product of the obligations imposed by the labor laws. Moreover, as suggested, the presence of a "bona fide, arm's-length" bargain eliminates any cause of action for the period of the agreement. The class action may continue, of course, but its focus would be limited to past injuries.

We can thus identify cases in which the labor policy of judicial non-intervention will take precedence over the general procedural rule calling for detailed review of class actions. But when we turn from the hypothetical situation discussed above to cases actually litigated, we get a less clear impression of the controlling effect of the labor law. As noted, in each of the player restraint cases involving a class action settlement-Robertson and Alexander-the court felt authorized to inquire into whether at least some features of the agreement were fair, reasonable, and adequate. At the same time, there was no direct discussion of how the labor policy of limited reviewability could be reconciled with this approach. Did the courts mean to suggest that labor law principles were not relevant to the settlements under review? Any such implication was probably not intended. But the explanation for the result in each of the cases differs, and it is appropriate to review them separately.

\section{B. The Robertson Settlement}

The agreement that terminated the Robertson class action included a provision for the payment of substantial damages by the defendant NBA clubs. ${ }^{123}$ Presumably these damages were to compensate the members of the plaintiff class for injuries allegedly resulting from the league's prior imposition of the restraints. But apart from the damages provision, the settlement had significant impact on the terms and conditions of the players' subsequent employment in the NBA. The settlement called for a continuation of a college draft and an arrangement for compensating clubs that lost players through free agency. ${ }^{124}$ As would be expected, a settlement of this sort was not undertaken without the involvement of

121. One complaint raised by NFL owners following the expiration of the 1970 collective bargaining agreement was that they were required to deal with the player restraint issues on two fronts: in court in the Mackey proceedings and at the collective bargaining table. See Oversight Hearings on National Football League Labor-Management Dispute: Hearings Before the Subcomm. on Labor-Management Relations of the House Comm. on Education and Labor, 94th Cong., 1st Sess., 51-55 (1975).

122. A collective bargaining agreement absent settlement of the class action is probably more theoretical than real. Each settlement will represent some cost to management, which is likely to desire that the overall cost be settled in a single undertaking. Similarly the union is likely to have an interest in keeping employer resources from being depleted by a settlement over which it has no control. See text accompanying notes 174-176 infra.

123. See 72 F.R.D. at 69

124. Details of the compensation arrangement, and some of the controversy that surrounded it, are considered in later proceedings in the Robertson class action. See In re Robertson Class Plaintiffs, 479 F. Supp. 657 (S.D.N.Y. 1979), affd in part, rev'd in part, 625 F.2d 407 (2d Cir. 1980) (Marvin Webster compensation dispute). After the 1980-81 season, the NBA's system for compensating teams that lost free agents 
the union which represented the league's active players and which, of course, had a legal duty to represent their interests in collective bargaining. In addition to class counsel and counsel for the league, the discussions leading to the agreement included representatives of the players' union. ${ }^{125}$ Moreover, apart from the settlement agreement in the class action, the league and the union entered into a collective bargaining agreement. ${ }^{126}$ As to matters covered by the settlement agreement, the collective bargaining agreement does not differ and the two arrangements were rather precisely coordinated.

For the future, then, the settlement agreement has essentially the same effect on the players as would a collective bargaining arrangement entered into in the absence of litigation. ${ }^{127}$ However, the settlement agreement has hardly operated like a labor contract as far as judicial intervention into its implementation is concerned. As previously indicated, there was an initial inquiry by the district court into the reasonableness, wisdom, and fairness of the new arrangement. The court's evaluation was fully approved on appeal without suggestion that labor law policies required a different approach. ${ }^{128}$ Still later there was another round of litigation-the now famous Marvin Webster compensation controversy-which found the district court involving itself in rather minute details of the industry's operation. ${ }^{129}$ In the Webster matter, for example, the trial court appraised whether the value of Rick Barry to his San Francisco team was greater or less than the value of Marvin Webster to the Seattle SuperSonics. ${ }^{130}$ While this question was relevant to the operation of the NBA's free agent compensation arrangement, the particular dispute represented the type of matter that is normally well-removed from judicial purview in the labor area. ${ }^{131}$ In neither the original proceeding reviewing the class action settlement nor in the subsequent Webster compensation litigation is there a discussion of how labor law concepts might have affected the analysis. In each proceeding, both the district court and the court of appeals assumed that the details of the settlement were proper matters for judicial scrutiny.

What is the explanation for this extensive judicial oversight? The most immediate explanation is that the court's detailed review was appropriate because the interested parties, including the union, had authorized it. This consent was critical

expired and was replaced by an arrangement under which the original employer had a right of first refusal based on the contract offered by the player's new club. See New York Times, May 19, 1981, at 20, col. 5. 125. See 72 F.R.D. at 66-67.

126. See Globe \& Mail (Toronto), April 13, 1976, at S2, col. 1 (NBA and NBA Players Ass'n reach 3 year collective bargaining agreement); Washington Post, Aug. 3, 1976, at D2, col. 3 (U.S. District Judge Carter approves collective bargaining agreement between NBA and NBA Players Ass'n).

127. The agreement fulfilled the important function of setting the terms of the players' employment for the future. See In re Robertson Class Plaintiffs, 479 F. Supp. 657, 662 (S.D.N.Y. 1979), affd in part, rev'd in part, 625 F. 2d 407 (2d Cir. 1980).

128. See 556 F.2d at $686-87$.

129. In re Robertson Class Plaintiffs, 479 F. Supp. 657 (S.D.N.Y. 1979), affd in part, rev'd in part, 625 F.2d 407 (2d Cir. 1980).

130. Id. at 663 .

131. See generally United Steelworkers v. Warrior \& Gulf Navigation Co., 363 U.S. 574 (1960); United Steelworkers v. Enterprise Wheel \& Car Corp., 363 U.S. 593 (1960); United Steelworkers v. American Mfg. Co., 363 U.S. 564 (1960); R. Gorman, Basic Text on LABOR LaW: Unionization and Collective Bargaining 540-74, 584-603 (1976); St. Antoine, Judicial Review of Labor Arbitration Awards: A Second Look at Enterprise Wheel and Its Progeny, $75 \mathrm{MiCH}$. L. REV. 1137 (1977). 
at the two stages of the proceedings mentioned above: when the class action settlement was initially reviewed and later, when the new compensation agreement was implemented. On the latter point, the judicial disposition of the Webster compensation controversy illustrates the extent to which the union and the league had involved the agreement in the normal judicial processes.

The parties specifically chose to commit the interpretation of their new arrangement to a district court special master rather than rely on the more traditional device of private arbitration. ${ }^{132}$ Moreover, the agreement expressly recognized the authority of the district court to review decisions of the special master and specified the standards for the court's review. ${ }^{133}$ The litigation which resulted from the Webster compensation controversy focused on the question of how closely the special master and the court could scrutinize initial compensation decisions made by the NBA Commissioner. Both the district court and the court of appeals agreed that the special master was not bound by the Commissioner's orders on compensation. ${ }^{134}$ Intervention by the special master was thought to be appropriate even when there was something less than an abuse of discretion by the Commissioner. Moreover, it was accepted that the district court had some limited authority to review the special master's findings.

In the course of the appeal of the Webster matter, the NBA made the argument that judicial review of the Commissioner's decisions on compensation should be limited because the judicial institutions lacked expertise in the difficult matter of evaluating a player's worth. ${ }^{135}$ Although not framed as an argument for application of the labor law policy of restraint, the league's contention sought to invoke a premise-the limited expertise of the courts-which was one consideration prompting judicial restraint in the review of other labor agreements. ${ }^{136}$ The court of appeals' response to this argument underscores the unusual nature of the Robertson settlement. The court observed:

We would not have been in the least displeased if the parties to the antitrust suit had settled
their differences on a basis that kept the amount of compensation awards completely
immune from judicial scrutiny. But they did not. Instead, the NBA, which now so ear-
nestly urges the court to stay out of the matter, decided to avoid the risk of antitrust lia-
bility adjudication by giving the court explicit authority to enforce an agreement that
contains a significant substantive limit on compensation awards. It was open to the NBA to
bargain for an interim compensation rule whereby the award of the Commissioner was final
not only between the teams, ... but also between the NBA and the players. Having
imposed upon the courts the obligation to enforce the terms of the agreement, ... the NBA
is in no position to complain when the court decides the matter that was entrusted to it. ${ }^{137}$

Thus, it appears that the provision for continuing judicial oversight of the new employment arrangement was not mandatory, and a union or employer involved in a subsequent settlement would be free to follow a course which took full advantage of the labor laws' preference for limited judicial review.

132. See 479 F. Supp. at 660.

133. See id. at 665-66.

134. See id. at 668-70; 625 F.2d at 412.

135. 625 F.2d at 414 .

136. See United Steelworkers v. American Mfg. Co., 363 U.S. 564, 567-68 (1960).

137. 625 F.2d at 414 . 
Why did the parties in Robertson not explore that course? Why did they not resist having the new agreement tested under the more exacting standards for class action settlements? The best explanation is probably found in the incomplete development of the labor exemption at the time of the Robertson settlement. The initial agreement was reached in February 1976.138 At that time, it looked extremely doubtful that antitrust immunity would attach to player restraints even if they were the product of bargaining. The most pertinent "law" on the availability of antitrust immunity consisted of several district court decisions, and none of these were encouraging for an employer's claim of immunity. The trial court decision in Mackey, for example, suggested that immunity could be claimed only by employees, that the restraints were not mandatory subjects of collective bargaining, and that any agreement on the restraints would be an illegal subject of bargaining. ${ }^{139}$ And, of course, the settlement was surely influenced by Judge Carter's prior pronouncements in Robertson itself. Especially noteworthy is the court's suggestion, discussed earlier, that the labor exemption only extends to matters clearly in the self-interest of employees. ${ }^{140}$ In short, the definition of the labor exemption had not yet been subject to the clarifying influence of either the Eighth Circuit's modification of the initial Mackey opinion or the Sixth Circuit's pronouncements in McCourt.

Given this state of relevant precedent, it is understandable that the labor participants in the settlement would accept a compromise which looked like a traditional litigation settlement, with continued judicial oversight, rather than a more private, more insular labor disposition. Any suggestion by management, or labor, that the new employment terms ought to be viewed as part of a collective bargaining agreement would have been met with the response that such treatment would afford no special status. Protection against further antitrust problems could be assured only if the new restraints were part of a settlement of the antitrust litigation. Such a settlement would seemingly require a substantial involvement by the court entertaining the claims. Hence, a settlement like that in Robertson was predictable.

This explanation should serve to identify why the Robertson settlement is not a particularly useful model for the future. It is now clearer that a compromise reached in collective bargaining preempts claims for prospective relief in the antitrust action. The parties thus need not feel themselves limited to the mechanism of ongoing judicial supervision selected in Robertson. Indeed if the pronouncements in at least three federal appeals court decisions are to be given weight, the preferred context for settling controversies about restraints is the collective bargaining process. ${ }^{141}$ Thus, if in the future the union and management were to assert greater

138. 72 F.R.D. at 66.

139. See 407 F. Supp. at 1008-09. No greater encouragement was offered by earlier decisions in Kapp v. NFL, 390 F. Supp. 73 (N.D. Cal. 1974) and Philadelphia World Hockey Club, Inc. v. Philadelphia Hockey Club, Inc., 351 F. Supp. 462 (E.D. Pa. 1972).

140. See 389 F. Supp. at 888-89, 895. See also text accompanying notes 35-39 supra.

141. See Reynolds v. NFL, 584 F.2d 280, 289 (8th Cir. 1978); Mackey v. NFL, 543 F.2d 606, 623 (8th Cir. 1976); Kansas City Royals Baseball Corp. v. Major League Baseball Players Ass'n, 532 F.2d 615, 632 (8th Cir. 1976). 
independence from judicial control, the new approach would proceed with the blessing of the more recent decisions.

\section{The Alexander Settlement}

By the time of the settlement of the Alexander class action, ${ }^{142}$ the immunizing effect of good faith collective bargaining had been established. It is understandable then that both the parties and the courts made a greater effort to treat the labor and class action aspects of the case as more distinct than they had been in Robertson. There was, for example, a separately denominated collective bargaining agreement which set forth the new rules to govern player movement within the league. ${ }^{143}$ The main focus of the class action settlement, on the other hand, was on setting monetary damages for prior injuries and to prescribe the formula for distributing these among class members. There was also a technical difference between the identity of the parties to the two agreements. The settlement was between the individual former and active players who comprised the plaintiff class and the league and clubs who were the defendants in that proceeding. ${ }^{144}$ The collective bargaining agreement, on the other hand, was between the players' union (NFLPA) and the NFL clubs.

Despite the presence of some distinctive features of the two agreements, the question of their true relationship was the source of some confusion in the proceedings to review the settlement. This lack of certainty in characterization was affected in no small measure by the fact that the two agreements were negotiated simultaneously. Moreover, while the class plaintiffs and the players' union had different lawyers representing them, the individuals involved were members of the same firm. ${ }^{145}$ Finally, the settlement agreement included important links with the labor contracts, including a covenant by class plaintiffs not to sue over the new player mobility rules found in the collective bargaining agreement. ${ }^{146}$

The uncertainty in the relationship between the two agreements ultimately led to a lack of precision in the review undertaken by the court. The imprecision is most evident in the district court opinion. It appears that the court would have liked to have been able to say that only the settlement agreement was before it; that the agreement dealt only with monetary relief for past injuries; and that since this was merely the settlement of a class action damage claim, the appropriate standard of review was whether the settlement was fair, adequate, and reasonable to class members. Much of the court's opinion is devoted to appraising these elements and reaching the conclusion that they are satisfied. Ultimately, however, the court cannot separate the collective bargaining agreement completely. Fifteen class members objected to the disposition of the original case. Most of these objections concerned the new player restraints found in the labor contract. In the words

142. 1977-2 Trade Cas. 161,730 (D. Minn.).

143. See id. at $72,985,72,997$.

144. Id. at $72,984,72,989$.

145. See id. at 73,002. Cf. Mungin v. Florida East Coast Ry. Co., 318 F. Supp. 720, $731-32$ (M.D. Fla. 1970), affd per curiam, 441 F.2d 728 (5th Cir. 1971) (no conflict found where same counsel represented both class plaintiffs and union).

146. See 1977-2 Trade Cas. at 72,997. 
of District Court Judge Larson, "Once the objectors . . had their collective foot in the door, the Court found it impossible to hold back the flood of evidence sought to be introduced on the propriety of the new Bargaining Agreement."147,

The district court is never quite clear as to exactly why the collective bargaining agreement was considered, a point which would seem to bear on the selection of the proper standard of review. In one passage the court states expressly that it does not view the collective bargaining agreement as part of the consideration for the settlement agreement. ${ }^{148}$ Yet, later in the opinion, the court suggests just the opposite. The court states that "the defendants were compelled to deal simultaneously with the NFL players' union and class counsel in attempting to resolve the issues posed by the Alexander case and in the collective bargaining negotiations . . . ."149 In the court's view, "no method existed for negotiating unrelated settlements on these issues."150 A further basis for doubting the court's initial conclusion that the collective bargaining agreement was not part of the consideration for the settlement agreement is the actual language used in the paragraph of the document which memorialized the settlement. That provision, which was not mentioned by the court, recites:

In consideration of the promises of the respective parties hereto as set forth herein, members of the Plaintiff class shall be entitled to receive the full and complete benefits and privileges of the Collective Bargaining Agreement on the terms and subject to the conditions therein set forth and shall in addition be entitled to receive a distribution from the $\$ 13,675,000$ in settlement monies ....151

The elements of the parties' exchange seem rather unmistakable in this passage. At a minimum, the language counsels against any judicial effort to place the two agreements in categories which are wholly distinct.

The district court ultimately found a link between the two, but, interestingly, this is founded in a provision of the settlement agreement other than that which recites the consideration. In the court's view, the collective bargaining agreement may be "implicated in the settlement" by virtue of a covenant under which plaintiffs agree not to sue to contest a range of provisions including the standard contract, the draft system, the waiver system, compensation rules, and, in general, the NFL Constitution and By-Laws. ${ }^{152}$ Since the covenant extended to player

147. Id. at 72,997 .

148. Id.

149. Id. at 73,001 .

150. Id.

151. Stipulation and Settlement Agreement I 6, Alexander v. National Football League, 4-76 Civ. 123, at 70a (D. Minn. Mar. 4, 1977) [emphasis added].

152. 1977-2 Trade Cas. at 72,997. The covenant not to sue provided:

Upon issuance of a final Court Order in this action certifying the Plaintiff Class as described in the preceding paragraph 3 as a Rule 23(b)(1) class and approving the settlement of this action on the terms and subject to the conditions set forth in this Agreement, the NFLPA, the Plaintiffs, and the members of Plaintiff Class each hereby covenant not to sue, nor support financially or administratively, any suit against the NFL or any club or against the Management Council with respect to any claim relating to any aspect of the NFL rules, including without limitation, the Standard Player Contract, the NFL Contract, the NFL Constitution and By-Laws, the college draft, the option clause, the right of first refusal or compensation, the "Rozelle Rule," the waiver system, the trading of players, tampering and the maintenance of certain reserve lists, all in the form in which they have been modified or agreed to in the Collective Bargaining Agreement or in any other form in which they may have 
restraints in the labor contract, the court thought some review was necessary.

The district court proceeded to consider in some depth the new player restraint rules found in the collective bargaining agreement. The court detailed various aspects of the draft, standard player contract, tampering rule and compensation rule. In addition, the extent of the parties' bargaining, and their good faith in the negotiations, received attention. The district court opinion does not state clearly the legal standard that was applied to the agreement. At times it appears that the court is asking whether the new terms were illegal, since the court cites precedent to the effect that class action settlements should not be approved if they involve illegalities. ${ }^{153}$ At other times, the court appears to be applying the standard for antitrust immunity announced in Mackey - that is, whether the new rules were the product of serious arm's-length collective bargaining. ${ }^{154}$ In general, though, it appears that the district court reviewed the collective bargaining agreement under the general standards of fairness, reasonableness, and adequacy which it believed must be applied to all class action settlements. ${ }^{155}$ Indeed, the inquiry takes the district court into the minutia of the agreement and the quality of the bargaining which preceded it. As suggested, the labor law authority for this sort of detailed review is not apparent, and the precedents that do exist would seem to foreclose it. ${ }^{156}$

When the Alexander case went to the Eighth Circuit, it appeared as Reynolds $v$. National Football League ${ }^{157}$ reflecting the fact that only Reynolds and a few others of the class plaintiffs chose to contest the district court's approval of the settlement agreement. The Eighth Circuit's opinion shares some of the equivocation found in Judge Larson's decision. Early in the opinion, the appellate court seems to have an unmistakable notion of how the labor contract and the settlement agreement are related: "the evidence fully supports the District Court's conclusion that the collective bargaining agreement was not part of the consideration for the class

existed at any time, or from time to time, during the 1972 season to and including the date of final Court approval of this Settlement Agreement; provided, however, that nothing contained in this paragraph 5 or in Section 2 of the Collective Bargaining Agreement will prevent the NFLPA or any player from asserting that any club, acting individually or in concert with other clubs, or the Management Council has breached the terms of this Settlement Agreement, or of the Collective Bargaining Agreement, the Standard Player Contract, the NFL Player Contract or the NFL Constitution and By-Laws, and from processing such asserted Breach as a non-injury grievance under the procedures set forth in Article VII of the Collective Bargaining Agreement; and provided further that such covenant not to sue shall not foreclose any member of the Plaintiff Class who has duly commenced an individual action, other than the actions referred to herein, in any Federal or State Court, prior to the date of the execution of this Stipulation and Settlement Agreement, from pursuing such action to its lawful conclusion through trial and appeal.

Stipulation and Settlement Agreement If 5, Alexander v. National Football League, 4-76 Civ. 123, at 69a$70 a$ (D. Minn. Mar. 4, 1977).

153. 1977-2 Trade Cas. at 72,999 (citing Grunin v. International House of Pancakes, 513 F.2d 114 (8th Cir. 1975), cert. denied, 423 U.S. 864 (1975)); In re Clark Oil \& Refining Corp. Antitrust Litigation, 422 F. Supp. 503 (E.D. Wis. 1976); Robertson v. NBA, 72 F.R.D. 64 (S.D.N.Y. 1976), affd, 556 F.2d 682 (2d Cir. 1977).

154. See 1977-2 Trade Cas. at ๆ 73,000-01.

155. See id. at $72,997-73,002$. The court set out in detail its view of the criteria relevant to the evaluation of the class action settlement. See id. at 72,992-93.

156. See notes $11-13,50,94-96$ supra and accompanying text.

157. 584 F.2d 280 (8th Cir. 1978). 
action settlement . . ."158 In the court's view, this serves to limit the controversy before it: "Thus the inquiry to be made by the district court in reviewing the proposed settlement and by this court in reviewing the district court's approval of that settlement is limited to the settlement itself rather than the labor agreement contained in the collective bargaining document."159 Later, however, the court presents a somewhat different view of the relationship between the two agreements. The court observes that "[a]lthough the collective bargaining agreement was negotiated contemporaneously with the settlement of this class action, it was not before the district court except as a circumstance bearing on the faimess of the settlement and the advisability of injunctive relief." 160 The exception here is susceptible to a very expansive reading. If the labor contract can affect the fairness of the settlement, and if it is theoretically possible that the approval of the settlement could be withheld because of overly harsh labor terms, the two hardly seem unrelated, as the court had initially suggested. Moreover, this statement by the court seems to undermine its earlier appraisal that the district court's review did not extend to the collective agreement.

This suggestion of a substantive link between the two is out of harmony with the general theme of the appellate opinion. Other portions of the opinion are consistent with the court's initial appraisal that it did not regard its review as necessitating consideration of the collective bargaining agreement. For example, the appellate court dealt with Judge Carter's view that the covenant not to sue linked the two agreements and required a review of the labor contract. The reviewing court specifically declined to make a similar appraisal. The court indicated that " $[w]$ hile the District Court findings on this matter seem amply supported by the evidence, it is not necessary for us to add any stamp of approval or disapproval to the collective bargaining agreement." 161 Thus, apart from the later intimation that the fairness of the settlement was linked to the labor contract, the appellate court was rather vigorous in attempting to put distance between the collective bargaining agreement and the particular proceedings before it.

There is no real reason to quibble with the result reached in Reynolds. It can be suggested, however, that the persuasive value of the decision is diminished by the court's failure to develop a coherent theory as to why the collective agreement was beyond its review. While the court states several times that a detailed appraisal of the labor contract is not required, the only rationale offered is the shaky premise that the labor contract was not part of the consideration for settlement. Given the fact that the settlement itself identified the collective bargaining agreement as part of its consideration, ${ }^{162}$ that the two were negotiated together, ${ }^{163}$ and that the plaintiff class enjoyed a close, nonadversarial relationship with the union, ${ }^{164}$ the validity of this assessment is not self-evident.

158. Id. at 282 .

159. Id.

160. Id. at 288 [emphasis added].

161. Id.

162. See text at note 151 supra.

163. See 1977-2 Trade Cas. at 72,984 n.2.

164. See text accompanying note 145 supra. 
The guidance provided by Reynolds would have been much clearer if the court had treated the lack of review of the labor contract as less discretionary. The court should have suggested that the judicial appraisal was foreclosed by relevant labor precedents. Such review would have been precluded in the absence of a pending class action. Since, as noted, the class' cause of action cannot encompass prospective injuries based on rules settled by robust collective bargaining, ${ }^{165}$ the presence of litigation on other matters should not change the result. Even if the negotiations for the settlement include a collective bargaining settlement, it does not follow that all aspects of the settlement are equally open to court review. ${ }^{166}$ One rather clear implication of this approach is that the district court's detailed review of the labor contract was not merely unnecessary, as the appellate court suggests, but, in fact, inappropriate. While it is true that the covenant not to compete provides a link between the two agreements, this connection does not require review of each component. The covenant simply presents a variation of the point made earlier: in every practical sense, the two agreements were connected. They did, however, have different legal status; there are particularized federal policies that prohibit the application of a fine-mesh standard of review to one of them. The fact that the plaintiff class promises not to sue over matters in the collective bargaining terms does not appear to present a sufficient reason for abandoning those sound labor policies. Such a promise is no more than an indication that the plaintiffs recognized that the negotiations which preceded the settlement had dual characteristics. Under this view, the substantive effect of the labor agreement does not change.

The IMPLICATIONS OF ROBERTSON AND ALEXANDER/REYNOLDS

Neither Robertson nor Alexander/Reynolds provides the most severe test for accommodating the different rules that define the respective reviewability of labor contracts and class action settlements. In each case, there was a high degree of cooperation, if not virtual identity of interest, between the players' union on the one hand and the plaintiff class representatives and their counsel on the other. ${ }^{167}$ Thus, there was no real competition between the two groups for the right to settle the various aspects of litigation. ${ }^{168}$ Also, the presentation of the issue of the nature of the court's review was largely the product of the parties' consent. As noted in Robertson, the union and management appear to have agreed to a fully particular-

165. See text accompanying note 120 supra.

166. Few cases explore this issue. There has, however, been a recognition that labor law principles will operate to modify the normal operation of rules on class actions. See In re Clark Oil \& Refining Corp. Antitrust Litigation, 422 F. Supp. 503, 508 (E.D. Wis. 1976). Cf. Mungin v. Florida East Coast Ry. Co., 318 F. Supp. 720, $731-32$ (M.D. Fla. 1970), affd per curiam, 441 F.2d 728 (5th Cir. 1971) (collective bargaining agreement approved as part of class settlement, even though some class members objected to the agreement).

167. See text accompanying notes $125-26,145$ supra.

168. Compare Mungin v. Florida East Coast Ry. Co., 318 F. Supp. 720, 731 (M.D. Fla. 1970), affd per curiam, 441 F. 2d 728 (5th Cir. 1971) (settlement initially negotiated without objection by class representative or union, but objection raised later). 
ized review of the new employment conditions. In Alexander/Reynolds, the areas offered for court review were not as extensive, but, again, it appears that there was no fundamental adversity between class counsel and the union on the issue of the reviewability of the collective bargaining agreement.

Such compatibility is not inevitable. An action such as Alexander could be brought by representatives less sympathetic to the union's position. Indeed, in retrospect it seems likely that the objectors in Alexander would have fared better in having their positions considered if they had initiated the class action. Any such proceeding that involves more distance between the representatives of the class and the union is likely to necessitate more careful consideration of the conflicting policies of reviewability.

One situation which might arise has already been discussed. If the union secures an agreement on future employment terms independent of the class action, this agreement should control any prospective class action remedies. As suggested earlier, if the threshold for effective union consent has been reached, the labor agreement should have the effect of extinguishing the class' claims concerning future injuries. ${ }^{169}$

An employer group that is also a defendant in a class action may not be anxious to negotiate separately with a union and with class action representatives. Could the employer-defendants insist that the union participate in joint bargaining with class representatives? Existing labor doctrine appears not to give the employer any such leverage. The labor statutes impose an affirmative duty on the employer to bargain with the union about the terms and conditions of employment. ${ }^{170}$ Neither the statute nor the case law suggests that this duty is qualified if the employer is involved in litigation with some portion of the employee group. ${ }^{171}$ It should not be startling to find that the employer owes legal duties to his employees which arise from different sources and that these may become actionable simultaneously. Moreover, our prior assumptions structure the issue so that the two groups-class representatives and union-will be negotiating about diffrent matters. The former seeks settlement for past injuries while the latter pursues changes which are prospective.

A somewhat different set of issues would be raised by the case in which the object of the union's efforts is not to compel separate collective bargaining, but rather to insert itself more directly into the prosecution of the class action. Indeed, the union might go so far as to demand either that it be substituted as class representative or that its attorney be substituted as counsel for the class. ${ }^{172}$ The basic question which is raised in these maneuvers concerns the right of the union to limit

169. See text accompanying notes $120-22$ supra.

170. See Labor Management Relations Act, 1947, 29 U.S.C. § 158(a) (1976); R. GoRMAN, BASIC Text on Labor law: Unionization and Collective Bargaining 506-09 (1976).

171. See, e.g., NLRB v. Dubo Mfg. Corp., 353 F.2d 157 (6th Cir. 1965).

172. See generally 7A C. Wright \& A. Miller, Federal Practice and Procedure \$§ 1765-69, 1794 (1972); Comment, The Importance of Being Adequate: Due Process Requirements in Class Actions Under Federal Rule 23, 123 U. PA. L. REv. 1217 (1975). The union might also seek to enter the litigation as an intervenor. See, e.g., Mungin v. Florida East Coast Ry. Co., 318 F. Supp. 720 (M.D. Fla. 1970), affd, per curiam, 441 F.2d 728 (5th Cir. 1971). 
the representation of employee interests by others. ${ }^{173}$

The union has available a number of arguments which suggest that it is a more appropriate representative than one which lacks the capacity to bargain collectively. One important contention is premised on what can be characterized as the "one-pie theory." All important concessions by the employers can likely be translated into the economic costs that they represent for the leagues. For a monetary settlement, the translation can be made readily. But, it would be urged, significant modification of player restraints also has economic costs. ${ }^{174}$ If players move more freely, the employers' expenditures for salaries are likely to go up. ${ }^{175}$ Relatedly, increased freedom of movement will reduce the value of the club's ability to market its reserve or option rights in its players. The essence of the one-pie theory is that there is only a single economic pool out of which the players' litigation and bargaining claims against the restraints can be satisfied. The union has the right to bargain for a share of this pie because of its status as the exclusive representative for collective bargaining purposes. The union may object, however, that its ability to fulfill its statutory duty could be seriously undermined if another employee representative also had a right to assert claims against the same asset pool. ${ }^{176} \mathrm{~A}$ large, overly generous monetary settlement to the class representative might seriously limit the type of agreement on new player restraints that the union could secure. To avoid this unnecessary, and perhaps disadvantageous, competition for the limited settlement pool, the union would urge that it should be accepted as the exclusive representative of the plaintiff class.

Implicit in this argument is a theme which has been given recognition in general class action litigation involving objections to the self-appointed class representative. Rule 23(a)(4) of the Federal Rules of Civil Procedure provides that a class action can be maintained only if "the representative parties will fairly and adequately protect the interests of the class."177 Interpretations of this section make clear that the issue of class representation touches on both the nature of the interest of the named representatives and the quality of class counsel. Among the objections which will be entertained by a court is the contention that the interests of the representatives or their counsel are not coextensive with the interests of the

173. Somewhat related issues arise when a union seeks to prosecute employment discrimination claims on behalf of its members. See, e.g., Air Line Stewards \& Stewardesses Ass'n, Local 550 v. American Airlines, Inc., 490 F.2d 636 (7th Cir. 1973), cert. denied, 416 U.S. 993 (1974); Deinhardt, Unions as Tille VII Plaintiff Class Representatives: A Potential Conflict of Roles and a Possible Solution, 1 Indus. ReL. L.J. 755 (1977).

174. See generally H. Demmert, The Economics of Professional Team Sports (1973); Canes, The Social Benefits of Restrictions on Team Quality, in GoVERNMENT AND THE SPORTS BUSINESS $81-113$ (R. Noll ed. 1974); Rottenberg, The Baseball Players' Labor Market, 64 J. Political ECONOMY 242 (1956).

175. Several sources have documented the effects of increased player mobility on player salaries. See, e.g., Kaplan, Is There a Ceiling.?, SPORTS Illustrated, Jan. 5, 1981, at 35-38; New York Times, Mar. 16, 1981, at $\mathrm{Cl}$, col. 1 .

176. One court that has allowed individual players to assert collective employee claims has suggested that such relief is appropriate "where from disloyalty, corruption, or other influences the Union has failed in its duty of faithful representation." Mungin v. Florida East Coast Ry. Co., 416 F.2d 1169, 1178 (5th Cir. 1969). While the quoted language might be read as a limitation on the right of employees to bring class actions, such a limitation was apparently not intended. See Mungin v. Florida East Coast Ry. Co., 441 F.2d 728 (5th Cir. 1971).

177. FED. R. Civ. P. 23(a)(4). 
class. ${ }^{178}$ Such a lack of cohesion may be found where the representatives have rights different from those of some class members, or where the representatives are likely to seek remedies which would not be desired by others in the class. ${ }^{179}$ The players' union contesting independent representation of the employee class would seem to have a colorable objection based on these principles. The independent representative lacks ultimate authority to deal with all aspects of the employees' complaints. The matter of settling future terms of employment has been reserved to the players' union and as just suggested, it can preempt any negotiations which the representative might undertake independently. Thus, it appears that the focus of the independent representative's efforts must be limited to monetary settlements for past injuries. But a settlement of this sort may not be wholly satisfactory to all class members. Some may, for example, desire a more complete resolution that treats both past injuries and future effects. As mentioned, an overly generous monetary settlement may limit the members' ability to secure the most desirable arrangements for future mobility. Moreover, the choice between the potential representatives is not an even one. Only the union has the capacity to act on the employer's behalf for all aspects of their complaints. It has ultimate authority to set future terms of employment, and it is not disqualified to raise claims for past injuries. The independent representative, however, lacks authority to set new work rules when the union is present. Thus, there appears to be a legitimate concern about whether its interest is coextensive with the player concerns that might exist. ${ }^{180}$

Does this mean that the union should always have the option of supplanting an independent class representative? The response must be negative because the selection of the representative is not a matter that can be treated in a categorical rule. ${ }^{181}$ The ultimate question is whether the class representation will be fair and adequate. This determination is highly contextual and particular cases may turn on facts wholly peculiar to their setting. The nature of the legal claim, the likelihood of a replication, the union's involvement in setting the rules being litigated, the presence of factions within the union, and even the competency of the union's attorney are matters relevant to the court's approval or disapproval of the existing representative. ${ }^{182}$ What can be suggested, though, is that a union's request to con-

178. See generally Eisen v. Carlisle \& Jacquelin, 391 F.2d 555, 562-63 (2d Cir. 1968); Advertising Specialty Nat'l Ass'n v. Federal Trade Comm'n, 238 F.2d 108, 119-20 (1st Cir. 1956); 7 C. WRIGHT \& A. Miller, Federal Practice and Procedure $\S \S 1768-9$ (1972).

179. See, e.g., Mixon v. Gray Drug Stores, Inc., 81 F.R.D. 413 (N.D. Ohio 1978) (plaintiff's estate could not repressent class employment discrimination suit because of lack of interest in prospective remedies); See generally 7 C. Wright \& A. Miller, Federal Practice and Procedure $\$ 1768$ (1972).

180. The class may include former employees, persons who are not presently part of the bargaining unit. Although bargaining for them is not mandatory, it is not precluded, and the union may properly seek employer consent to deal with the claims of retirees. See Allied Chemical \& Alkali Workers, Local 1 v. Pittsburgh Plate Glass Co., 404 U.S. 157, 176-79 (1971); R. Gorman, BASIC TeXT ON LABOR LAW: Unionization and Collective Bargaining 528-29 (1976).

181. See, e.g., Pettway v. American Cast Iron Pipe Co., 576 F.2d 1157, 1177-80 (5th Cir. 1978), cert. denied, 439 U.S. 1115 (1979); Green v. Wolf Corp., 406 F.2d 291, 298-99 (2d Cir. 1968), cert. denied, 395 U.S. 977 (1969); Eisen v. Carlisle \& Jacquelin, 391 F.2d 555, 562 (2d Cir. 1968).

182. Compare Sperry Rand Corp. v. Larson, 554 F.2d 868, 874 (8th Cir. 1977) (union approved as class representative) with Air Line Stewards \& Stewardesses Asss'n, Local 550 v. American Airlines, Inc., 490 F.2d 636 (7th Cir. 1973), cert. denied, 416 U.S. 993 (1974) (union found not to be adequate representative). 
trol the class litigation is not to be lightly dismissed, and general class action precedents would seem to offer encouragement to the union concerned about losing control of important employee-related litigation.

\section{IV \\ CONCLUSION}

This paper has considered two matters which, on the surface at least, appear to be quite distinct. One concerns the threshold for employer invocation of the protection of labor's antitrust exemption where labor market restraints are involved. The other involves the relationship between class action settlements and collective bargaining. An implication of this paper is that there is, in fact, a significant common thread that joins these issues. Specifically, each topic raises a variation of the basic question of the extent to which courts ought to intervene to evaluate the substantive and procedural aspects of traditional collective bargaining.

A major premise of this paper has been that sound labor policy counsels in favor of minimal judicial involvement in appraising the reasonableness of collective agreements. A good deal of authority, from the Supreme Court and elsewhere, seems to accept this assessment. It is not suggested, of course, that the preference for judicial non-intervention is without exception. As the player restraint/labor exemption cases have made clear, a blind adherence to the policy would protect wholly unilateral employer action and subvert the goal of the labor exemption to encourage employees to define their own self-interest. ${ }^{183}$ The recent sports industry litigation has served to reaffirm the need for rethinking how labor, antitrust, and class action policies will be accommodated at their margins.

The prior discussion has attempted to suggest that the recent judicial considerations of these issues have not always produced clear definitions of the respective roles of the competing policies. Perhaps understandably, there has been a tendency to view the problems apart from their general labor context with undue deference to general class action principles and, in the labor exemption area, a standard of review which has its origins in earlier dicta. The suggestion made here is that the results achieved in these areas are likely to be more satisfactory if there is explicit respect for the autonomy of the collective bargaining process. This policy of not requiring governmental approval of labor contracts has worked well in other contexts. Antitrust and class action concerns may require some adjustments. But these should be regarded as true exceptions warranting narrow definitions. What both the antitrust and class action sports cases seem to reveal is that where there is an agreement which is clearly the product of a robust labor-management give and take, little is to be gained by upsetting it. It is likely that the courts would do no better at structuring the "right" accommodation of competing interests. The courts to date have generally achieved this result, but under standards and doctrines which are sometimes troublesome in their future implications and sometimes unpersuasive. A clearer, less equivocal embrace of the notion that the labor agreement is predominant seems to provide a preferable guide for the future.

183. See notes 25.30 supra and accompanying text. 